\title{
Monoaminergic Neuromodulation of Sensory Processing
}

\author{
Simon N. Jacob ${ }^{1 *}$ and Hendrikje Nienborg ${ }^{2 *}$ \\ 'Department of Neurosurgery, Klinikum Rechts der Isar, Technical University of Munich, Munich, Germany, \\ ${ }^{2}$ Werner Reichardt Centre for Integrative Neuroscience, University of Tübingen, Tübingen, Germany
}

\section{OPEN ACCESS}

Edited by:

Anita Disney,

Vanderbilt University, United States

Reviewed by:

Summer Sheremata, Florida Atlantic University,

United States

Adam C. Snyder,

University of Pittsburgh, United States

Susan J. Sara,

Collège de France, France

*Correspondence:

Simon N. Jacob

simon.jacob@tum.de

Hendrikje Nienborg

hendrikje.nienborg@cin.uni-

tuebingen.de

Received: 11 November 2017 Accepted: 11 June 2018

Published: 10 July 2018

Citation:

Jacob SN and Nienborg H (2018) Monoaminergic Neuromodulation

of Sensory Processing.

Front. Neural Circuits 12:51. doi: 10.3389/fncir.2018.00051
All neuronal circuits are subject to neuromodulation. Modulatory effects on neuronal processing and resulting behavioral changes are most commonly reported for higher order cognitive brain functions. Comparatively little is known about how neuromodulators shape processing in sensory brain areas that provide the signals for downstream regions to operate on. In this article, we review the current knowledge about how the monoamine neuromodulators serotonin, dopamine and noradrenaline influence the representation of sensory stimuli in the mammalian sensory system. We review the functional organization of the monoaminergic brainstem neuromodulatory systems in relation to their role for sensory processing and summarize recent neurophysiological evidence showing that monoamines have diverse effects on early sensory processing, including changes in gain and in the precision of neuronal responses to sensory inputs. We also highlight the substantial evidence for complementarity between these neuromodulatory systems with different patterns of innervation across brain areas and cortical layers as well as distinct neuromodulatory actions. Studying the effects of neuromodulators at various target sites is a crucial step in the development of a mechanistic understanding of neuronal information processing in the healthy brain and in the generation and maintenance of mental diseases.

Keywords: serotonin, dopamine, noradrenaline, primary sensory cortex, primary visual cortex (V1), primary auditory cortex, early sensory processing

\section{INTRODUCTION}

Even at the earliest stages of sensory processing, the neuronal representation of external stimuli is modulated by internal brain states (Aston-Jones and Cohen, 2005; Harris and Thiele, 2011). While the evidence for such modulation is long-standing, the analysis of sensory representations has typically focused on the feed-forward stimulus-driven component while regarding the modulation by internal states as noise. However, recent results based on population recordings (Reimer et al., 2014; Rabinowitz et al., 2015; Schölvinck et al., 2015) that highlight the extent of brain-state dependent modulation of sensory processing, the discovery of substantial modulation of sensory activity with locomotion (Niell and Stryker, 2010; Polack et al., 2013), as well as novel tools to more selectively target modulatory circuit elements genetically have contributed to reviving the interest in the neuromodulation of sensory processing. Since the role of acetylcholine has received substantial attention and has been the subject of excellent recent reviews (Sarter et al., 2009; Harris and Thiele, 2011), we will focus here on the modulation by the monoamines dopamine (DA), noradrenaline (NA), and serotonin (5HT). For each of these modulatory systems, we will summarize anatomical data and electrophysiological findings to provide insights into their role in 
the modulation of sensory processing, placing an emphasis on studies in non-human primates and rodents, and highlighting the complementarity of these neuromodulatory systems (Figure 1). We will cover key classical studies and then shift our focus toward more recent work.

\section{SEROTONERGIC MODULATION OF SENSORY PROCESSING}

\section{Serotonin Sources}

Serotonin-synthesizing neurons are located in the brainstem in a small group of clusters [named B1-B9 after Dahlström and Fuxe (1964)]. These were first identified in the rat brain (Dahlström and Fuxe, 1964) but their anatomical localizations in mouse and primate species, e.g., Jacobowitz and MacLean (1978), have been found to be largely consistent with that in the rat. These clusters are typically divided into a caudal and a rostral group (Hornung, 2010). The caudal group, which consists of the raphe pallidus (B1), the raphe obscurus (B2), and raphe magnus (B3) (Lesch and Waider, 2012), projects mainly to the spinal cord and brain stem. The rostral group includes the dorsal raphe nucleus $(\mathrm{B} 6, \mathrm{~B} 7)$ and the median raphe nucleus $(\mathrm{B} 5, \mathrm{~B} 8$, and B9) and projects to the cortex. Within this group, there is some topographic organization of the serotonergic innervation (Hornung, 2010) that reflects a rostral (frontal cortex) to caudal (occipital cortex) gradient (Wilson and Molliver, 1991b). Such topographical organization suggests that rather than reflecting a signal that is broadcasted uniformly throughout the brain, serotonergic projections to different areas are more specific and may serve different roles. Indeed, retrograde studies in rats support topographically specific projections, for example to the prefrontal cortex (PFC) (Chandler et al., 2013). Although

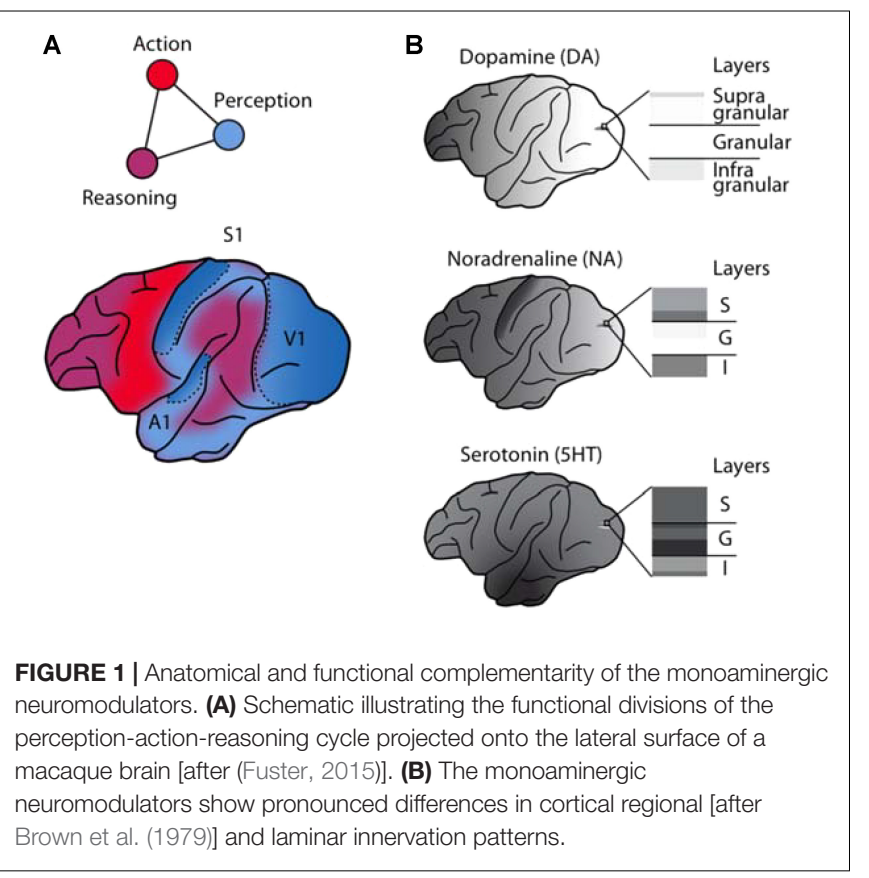

serotonergic neurons represent only a very small number of the neurons in the brain [approx. 28,000 in the mouse (Ishimura et al., 1988) to several 100,000 in humans (Hornung, 2010)], they give rise to diverging projections to virtually all regions of the mammalian brain (Hornung, 2010). Here, we will focus on the serotonergic projections to primary sensory cortical areas and subcortical structures involved in sensory processing.

\section{Serotonergic Projections to Early Sensory Areas}

Anatomical studies in different rodent and monkey species have identified substantial serotonergic projections from the raphe nuclei to early sensory areas including the primary auditory, visual, and somatosensory areas, the olfactory bulb, and subcortical structures involved in sensory processing (Table 1). [Note that while in the auditory system, serotonergic innervation of the cochlear nucleus is established (Klepper and Herbert, 1991), serotonergic projections to the retina have been controversial (Schnyder and Künzle, 1984; Frazão et al., 2008)].

Comparisons of monoaminergic innervation found that the serotonergic innervation was substantially more pronounced than that for NA or DA in the macaque primary auditory cortex (Campbell et al., 1987) and in the macaque primary visual cortex (Morrison et al., 1982a; Kosofsky et al., 1984; Morrison and Foote, 1986; Lewis et al., 1987). This pattern mirrors early reports of regional differences in cortical monoaminergic distribution (Brown et al., 1979), with a pronounced decrease in DA from frontal to occipital cortex, a weaker gradient (interrupted by a peak in the somatosensory cortex) for NA, and a roughly uniform distribution for serotonin (Figure 1B).

Within primary sensory cortical areas, the distribution of serotonergic fibers in primates shows a characteristic laminar profile. In the primary visual cortex, anatomical data for different primate species agree that the distribution of serotonergic axons is highest in layer 4 (Kosofsky et al., 1984; Morrison and Foote, 1986). This suggests that the serotonergic modulation in the primary visual cortex is biased toward targeting the visual input stage. Serotonergic fibers are also consistently found in cortical layer 4 in the primary auditory cortex (Campbell et al., 1987) and somatosensory cortex (Wilson and Molliver, 1991a,b), although not preferentially.

This contrasts with the monoaminergic innervation of primary sensory areas by NA and DA (see below) that is typically sparse if not absent in layer 4 (Figure 1B). (Note that while a transient dominance of serotonergic input to layer 4 occurs during the early post-natal development in the rodent primary visual cortex and barrel cortex (Fujimiya et al., 1986; Dori et al., 1996), regional and laminar differences are less pronounced in rodents than in the primate species.)

Consistent serotonergic innervation is also found in subcortical structures involved in sensory processing such as the sensory thalamus (Vertes et al., 2010), the superior (Dori et al., 1998) and inferior (Klepper and Herbert, 1991) colliculi, and the cochlear nucleus (Klepper and Herbert, 1991). In the olfactory bulb, serotonergic fibers reach the glomerular layer, the primary input stage (Takeuchi et al., 1982). Together, the 
TABLE 1 | Anatomical findings for the serotonin system in early sensory areas.

\begin{tabular}{|c|c|c|c|}
\hline Sensory area & Species & Significance & Reference \\
\hline V1 & Squirrel monkey & $\begin{array}{l}\text { V1 receives substantial projections from medial and dorsal raphe nucleus. } \\
\text { Serotonergic fibers preferentially target layer } 4 \text { in } V 1 \text {. }\end{array}$ & $\begin{array}{l}\text { Morrison et al., 1982a; Tigges } \\
\text { et al., } 1982\end{array}$ \\
\hline V1 & $\begin{array}{l}\text { Macaca fascicularis } \\
\text { and nemestria }\end{array}$ & V1 receives substantial projections from the dorsal and medial raphe nuclei. & Doty, 1983 \\
\hline V1 & Macaca fascicularis & $\begin{array}{l}\text { Serotonergic fibers most pronounced in the layers } 3-4 \mathrm{C} \alpha \text { in } \mathrm{V} 1 \text { and overall } \\
\text { denser than NA fibers }\end{array}$ & $\begin{array}{l}\text { Kosofsky et al., 1984; de Lima } \\
\text { et al., } 1988\end{array}$ \\
\hline V1 & Macaca fuscata & $\begin{array}{l}\text { Serotonergic varicosities are densest in layer } 4 \mathrm{C} \alpha \text {, and in contact with stellate } \\
\text { and pyramidal neurons. }\end{array}$ & Takeuchi and Sano, 1984 \\
\hline V1 & $\begin{array}{l}\text { Macaca fuscata } \\
\text { and fascicularis }\end{array}$ & $\begin{array}{l}\text { Detailed laminar profile of } 5 \mathrm{HT} \text { receptor expression. } 5 \mathrm{HT} 1_{\mathrm{B}} \text { and } 5 \mathrm{HT} 2_{\mathrm{A}} \text { are most } \\
\text { pronounced. Expressed in layers } 2-6 \text {, most pronounced in layer } 4 \mathrm{~A} \text { and } 4 \mathrm{C} \alpha / \beta \text {. }\end{array}$ & Watakabe et al., 2009 \\
\hline V1 & Rat & $\begin{array}{l}\text { Transient increase during development in layer 4; later fairly uniform } \\
\text { serotonergic innervation across layers. }\end{array}$ & Dori et al., 1996 \\
\hline V1 & Rat & $\begin{array}{l}\text { Serotonergic fibers in all layers but most pronounced in layer } 4 \text {. Target } \\
\text { pyramidal and interneurons. Among inhibitory interneurons, mostly } \\
\text { somatostatin and NPY+ neurons but VIP+ interneurons are avoided. }\end{array}$ & $\begin{array}{l}\text { Paspalas and Papadopoulos, } \\
2001\end{array}$ \\
\hline LGN & Rat & $\begin{array}{l}\text { Serotonergic projections identified using retrograde labeling; dense } \\
\text { immunolabelling for the serotonin transporter (SERT), a sensitive marker for } \\
\text { serotonergic fibers; most pronounced in the VLGN and IGL of the LGN complex }\end{array}$ & $\begin{array}{l}\text { Villar et al., 1988; } \\
\text { Papadopoulos and Parnavelas, } \\
\text { 1990; Vertes et al., } 2010\end{array}$ \\
\hline S1 & Mouse & $5 \mathrm{HT}_{\mathrm{A}}$ receptor is expressed on most non-PV, non-SST inhibitory interneurons & Rudy et al., 2011 \\
\hline S1 & Mouse & $\begin{array}{l}\text { Innervation across all layers in the adult. Transient increase during postnatal } \\
\text { development ( PDD). Similar to the rat. }\end{array}$ & Fujimiya et al., 1986 \\
\hline S1 & Macaca fascicularis & $\begin{array}{l}\text { (Areas } 1,2,3) 5 \mathrm{HT} \text { fibers across all layers but least pronounced in the lower } \\
\text { part of layer } 3 \text { and layer } 4 .\end{array}$ & DeFelipe and Jones, 1988 \\
\hline S1 & $\begin{array}{l}\text { Macaca mulatta } \\
\text { and fascicularis }\end{array}$ & Fairly uniform distribution of serotonergic fibers across layers in S1. & Wilson and Molliver, 1991a,b \\
\hline S1 & Rat & $\begin{array}{l}\text { 5HT fibers are most pronounced superficially, but some controversy; } 5 \mathrm{HT} \\
\text { concentration measured voltammetrically is highest in superficial layers and } \\
\text { decreases toward deeper layers; Transient increase in layer } 4 \text { during } \\
\text { development, later fairly uniform. }\end{array}$ & $\begin{array}{l}\text { Fuxe, 1965; Beaudet and } \\
\text { Descarries, 1976; Lamour } \\
\text { et al., 1983; Dori et al., } 1996\end{array}$ \\
\hline Inferior colliculus & & $\begin{array}{l}\text { Dense but complementary } 5 \mathrm{HT} \text { and NA projections in both IC and cochlear } \\
\text { nucleus. }\end{array}$ & Klepper and Herbert, 1991 \\
\hline A1 & Cat & $5 \mathrm{HT}$ innervation mostly restricted to layers $1-3$. & DeFelipe et al., 1991 \\
\hline A1 & Macaca fascicularis & "Uniformly high density" across all layers. & Campbell et al., 1987 \\
\hline MGN & Rat & Homogenous serotonergic innervation. & Vertes et al., 2010 \\
\hline SC & Rat & $\begin{array}{l}\text { Serotonergic fibers throughout, but more pronounced in the superficial than in } \\
\text { the deep layers of the SC. }\end{array}$ & $\begin{array}{l}\text { Villar et al., 1988; Dori et al., } \\
1998\end{array}$ \\
\hline Olfactory bulb & Rat & $\begin{array}{l}\text { Projections from dorsal and median raphe to all layers of olfactory bulb; most } \\
\text { densely in glomerular layer, i.e., the input layer. }\end{array}$ & McLean and Shipley, 1987 \\
\hline
\end{tabular}

extent of serotonergic innervation at the earliest stages of sensory processing makes this system well suited to directly modulate the incoming sensory information.

\section{Serotonergic Synapses and Receptors}

The serotonergic projections to the primary sensory areas consist of small varicose axons that are widely distributed (Hornung, 2010). Only a very small proportion of synaptic specializations, typically asymmetric, is found (Descarries et al., 2010), suggesting that serotonin predominantly acts by volume transmission from varicosities. Note, however, that the degree to which neuromodulatory systems rely on "wired" transmission, i.e., highly localized and typically synaptic, or "volume" transmission, i.e., more spatially diffuse, is subject to debate (e.g., Rice and Cragg, 2008; Sarter et al., 2009; Fuxe and Borroto-Escuela, 2016; Sulzer et al., 2016). In the mammalian brain, seven serotonin receptor families, most with several subtypes, have been identified to date and contribute to the functional diversity of serotonin
(Mengod et al., 2010). A detailed overview is outside the scope of this review, but a few receptors should be highlighted. 5HT1A is expressed on cortical pyramidal neurons (DeFelipe et al., 2001). In the macaque primary visual cortex, the most densely expressed receptors are 5HT1B and 5HT2A (Watakabe et al., 2009), predominantly in layer 4. 5HT1B is also strongly expressed in the LGN, but only weakly in other cortical areas including the auditory and somatosensory cortex (Watakabe et al., 2009). In the mouse, GABAergic neurons that express the 5HT3A do not express the calcium binding protein parvalbumin or somatostatin and may form a third non-overlapping class of inhibitory interneurons (Rudy et al., 2011).

\section{Serotonergic Modulation of Sensory Physiology}

Given the complexity of the input to serotonergic neurons (Pollak Dorocic et al., 2014), the wide distribution of serotonergic projections in the brain and the diversity of serotonin receptors, it 
is unsurprising that serotonin has been implicated in a spectrum of brain functions. These include the sleep-wake cycle, hormonal regulation, regulation during development as well as affective, cognitive, and sensorimotor functions. Serotonergic neurons show tonic and phasic modes of discharge that are thought to signal different information. For example, in the mouse transient responses of putative serotonergic neurons in the dorsal raphe nucleus reflect a variety of behavioral, sensorimotor, and rewardlinked information (Ranade and Mainen, 2009). Phasic and tonic response patterns of optogenetically identified serotonergic neurons in the mouse dorsal raphe have been proposed to reflect the contextual valence on different time-scales (Cohen et al., 2015). Serotonergic neurons have also been linked to signaling patience (Fonseca et al., 2015). But, even for the intensely studied links to reward signaling a simple computational account has proved challenging (Ranade et al., 2014; Dayan and Huys, 2015). Although it is unclear whether its modulatory role can be conceptualized by a simple overarching computational function, serotonin is thought to modulate sensory processing according to behavioral-motivational context.

In reviewing studies of serotonergic modulation of early sensory processing across modalities, consistencies are notable, which will be our focus here (Table 2). This focus contrasts with previous perspectives highlighting the diversity of findings (Hurley et al., 2004). (Note that we restricted this summary to studies of short-term sensory modulation and did not consider reports on adaptation or plasticity.) Some variability in the findings likely results from comparing results across anesthetized animals using different anesthetics or awake animals and different experimental approaches.

Despite this variability, most findings are consistent with an overall serotonin-mediated decrease of the sensory response. In the auditory system, a decrease of the extracellular response was observed for the majority of neurons both in the cochlear nucleus of the rat (Ebert and Ostwald, 1992) and the inferior colliculus (IC) of bats (Hurley and Pollak, 1999), although some variability of the effects between cells was observed. Behaviorally, a reduced startle response to auditory tones was observed for intraventricular injection of serotonin (Davis et al., 1980), which is consistent with reduced auditory response (but could also reflect downstream processing). Similarly, a reduced mechanosensory response was observed in behaving mice during optogenetic stimulation of serotonergic raphe neurons (Dugué et al., 2014), which could reflect downstream processing but would also be expected for a reduced sensory response in the somatosensory cortex as previously reported (Waterhouse et al., 1986).

For early visual processing, predominantly decreased responses were observed for the iontophoretic application of serotonin in the cat lateral geniculate nucleus (LGN) (Phillis et al., 1967) and rat V1 (Waterhouse et al., 1990). In the anesthetized macaque, when attempting to dissect the role of the two most strongly expressed receptors in V1, 5HT1B and 5HT2A, using receptor specific ligands, a diverse pattern and bi-directional modulation were observed for both (Watakabe et al., 2009). However, these effects were not compared to spontaneous variability of the responses resulting from the anesthesia or the iontophoretic application itself. For example, slow fluctuations in the neuronal responses have been shown to contribute to stimulus-independent co-variability ("noise correlations") between neurons (Ecker et al., 2014). When instead iontophoretically applying the endogenous ligand serotonin in awake macaques and comparing the effects against those of $\mathrm{pH}$ matched saline application, a recent study found an overall decrease of the sensory responses with serotonin (Seillier et al., 2017). While there was some variability across cells, consistent with the results of Watakabe et al. (2009), the inhibitory effect of serotonin was the dominant pattern across the sizeable neuronal population. This decrease was predominantly explained by a multiplicative change (gain change) of the neuronal tuning curves. Behaviorally, a recent study that systemically administered a serotonin-reuptake inhibitor to enhance the effect of serotonin while macaques performed a color discrimination task observed slowed reaction times as well as deteriorated perceptual performance (Costa et al., 2016), as expected for such reduced visual responses. Conversely, a gain reduction of the spontaneous response (Lottem et al., 2016), consistent with an increased signal-to-noise ratio (SNR), or a gain reduction of the tuning curves (Petzold et al., 2009) for serotonin was observed in the mouse olfactory bulb.

Taken together, a surprisingly consistent pattern of the serotonergic modulation of early sensory processing across modalities emerges. The decreased sensory response by serotonin - effectively lowering the salience of the sensory input - may reflect a sensory signature of how serotonin shapes behavior in downstream circuits, such as its proposed role as a behavioral inhibitor (Soubrie, 1986), to promote waiting (Miyazaki et al., 2014; Ranade et al., 2014; Fonseca et al., 2015) or persistence (Lottem et al., 2018).

\section{NORADRENERGIC MODULATION OF SENSORY PROCESSING}

\section{Noradrenergic Sources}

In rodents (Dahlström and Fuxe, 1964) and primates (Jacobowitz and MacLean, 1978), neurons that produce NA are located in the brainstem in clusters named A1-A7 after (Dahlström and Fuxe, 1964). Of these, the locus coeruleus (LC, A6) projects to most areas in the brain (Loughlin et al., 1986), except for to the basal ganglia [reviewed in Berridge and Waterhouse (2003)], and is the sole source of the noradrenergic innervation of the cerebral cortex (Jones et al., 1977; Moore and Bloom, 1979). Immunohistochemical evidence indicates that within the LC the vast majority of neurons are noradrenergic (Grzanna and Molliver, 1980). Similar to the serotonergic and dopaminergic systems, the absolute number of noradrenergic neurons in the LC is small [estimated between approx. 1500 per hemisphere in rodents and approx. 15,000 per hemisphere in humans, reviewed in Sara and Bouret (2012)], but the projections of these neurons are divergent and wide-spread throughout the brain. Despite these wide-spread projections recent findings indicate a modular organization of the LC in rats (Uematsu et al., 2017) and substantial anatomical specificity of the connections, for example 
TABLE 2 | Findings related to sensory modulation by serotonin.

\begin{tabular}{|c|c|c|c|}
\hline Sensory area & $\begin{array}{l}\text { Species and anesthesia, } \\
\text { if applicable }\end{array}$ & Significance & Reference \\
\hline Cochlear nucleus & Urethane anesthetized rat & $\begin{array}{l}\text { Mostly suppressive effect of iontophoretically applied } 5 \mathrm{HT} \text { on } \\
\text { extracellular responses }\end{array}$ & $\begin{array}{l}\text { Ebert and Ostwald, } \\
1992\end{array}$ \\
\hline Inferior colliculus & $\begin{array}{l}\text { Lightly anesthetized } \\
\text { (ketamine/xylazine) Bat }\end{array}$ & $\begin{array}{l}\text { Multiplicative decrease of response with iontophoretic } 5 \text { HT application; } \\
\text { weak increase in latency }\end{array}$ & $\begin{array}{l}\text { Hurley and Pollak, } \\
\text { 1999, } 2005\end{array}$ \\
\hline $\begin{array}{l}\text { Putative auditory } \\
\text { contribution }\end{array}$ & Behaving rat & $\begin{array}{l}\text { Startle response to auditory white noise is reduced by intraventricular } \\
5 \mathrm{HT} \text { application }\end{array}$ & Davis et al., 1980 \\
\hline $\mathrm{V}_{1}$ & $\begin{array}{l}\text { Anesthetized } \\
\text { (isoflurane/droperidol/fentanyl) } \\
\text { macaque }\end{array}$ & $\begin{array}{l}\text { Variable bidirectional modulation of extracellular responses with } \\
\text { application of } 5 \mathrm{HT} 1_{\mathrm{B}} \text { and } 5 \mathrm{HT} 2_{\mathrm{A}} \text { receptor selective agents }\end{array}$ & $\begin{array}{l}\text { Watakabe et al., } \\
2009\end{array}$ \\
\hline V1 & $\begin{array}{l}\text { Anesthetized } \\
\text { (fentanyl/thiopental/succinylcholine } \\
\text { chloride) macaque }\end{array}$ & $\begin{array}{l}\text { Intracortical injection of } 5 \mathrm{HT}^{\mathrm{A}} \text { agonist decreases extracellularly } \\
\text { recorded responses }\end{array}$ & Rauch et al., 2008 \\
\hline $\mathrm{V}_{1}$ & Behaving macaque & $\begin{array}{l}\text { Gain decrease of extracellular responses with iontophoretic } 5 \mathrm{HT} \\
\text { application. Modest increase in response latency. No systematic effect } \\
\text { on response variability, co-variability, or selectivity }\end{array}$ & Seillier et al., 2017 \\
\hline $\mathrm{V}_{1}$ & Halothane anesthetized rat & $\begin{array}{l}\text { Variable findings for iontophoretic } 5 \mathrm{HT} \text { application but mainly a } \\
\text { decreased response across the population }\end{array}$ & $\begin{array}{l}\text { Waterhouse et al., } \\
1990\end{array}$ \\
\hline dLGN & $\begin{array}{l}\text { Halothane/nitrous oxide } \\
\text { anesthetized cat }\end{array}$ & $\begin{array}{l}\text { Decrease of the extracellular responses for iontophoretic } 5 \mathrm{HT} \\
\text { application }\end{array}$ & Phillis et al., 1967 \\
\hline \multirow[t]{3}{*}{ S1 } & Halothane anesthetized rat & $\begin{array}{l}\text { Suppression of response to tactile stimuli (forepaw touch), consistent } \\
\text { with response gain decrease with iontophoretic } 5 \mathrm{HT} \text { application }\end{array}$ & $\begin{array}{l}\text { Waterhouse et al., } \\
1986\end{array}$ \\
\hline & Behaving mouse & $\begin{array}{l}\text { Decreased mechanosensory response of mice during optogenetic } \\
\text { activation of serotonergic raphe neurons }\end{array}$ & Dugué et al., 2014 \\
\hline & Behaving macaque & $\begin{array}{l}\text { Blocking serotonin re-uptake slowed reaction times and worsened } \\
\text { perceptual performance in a visual (color) discrimination task }\end{array}$ & Costa et al., 2016 \\
\hline Olfactory bulb & $\begin{array}{l}\text { Ketamine/xylazine } \\
\text { anesthetized mouse }\end{array}$ & $\begin{array}{l}\text { Gain decrease for application of } 5 \mathrm{HT} \text { agonists, reversed for application } \\
\text { of } 5 \mathrm{HT} \text { antagonist. }\end{array}$ & Petzold et al., 2009 \\
\hline Olfactory bulb & $\begin{array}{l}\text { Urethane anesthetized } \\
\text { mouse }\end{array}$ & $\begin{array}{l}\text { Optogenetic activation of serotonergic neurons in the dorsal raphe lead } \\
\text { to a gain decrease of spontaneous but not stimulus-driven extracellular } \\
\text { response in the OB resulting in an increase in SNR }\end{array}$ & Lottem et al., 2016 \\
\hline
\end{tabular}

to the prefrontal versus the motor cortex (Chandler et al., 2014), or different modules projecting to the amygdala compared to the medial PFC (mPFC) (Uematsu et al., 2017). It therefore seems likely that at least some degree of modularity is also characteristic of projections to sensory areas. In the following, we will again focus on the projections to the primary sensory areas and subcortical structures involved in early sensory processing.

\section{Noradrenergic Projections to Early Sensory Areas}

The LC sends divergent projections to the cortex and subcortical structures. Within the LC, these projections are roughly topographically organized [reviewed in Berridge and Waterhouse (2003)]. In the rat, cortex-projecting neurons are more prominent in the caudal portion of the LC and show some ventral (frontal cortex) to dorsal (occipital cortex) organization (Waterhouse et al., 1983). Despite the rough topography, a recent study combining retrograde labeling and optogenetic stimulation in the mouse found that the LC projections to primary sensory cortices are not modality-specific (Kim et al., 2016) (contrasting with these authors' findings for the cholinergic system). Nonetheless, projections from LC show clear regional differences (Table 3). Early studies in rats (Kehr et al., 1976) and macaques (Brown et al., 1979) observed an overall frontal (higher concentration) to occipital (lower concentration) gradient of NA throughout cortex, with the exception of somatosensory cortex where the concentration was highest (Brown et al., 1979). This gradient was weaker than that for DA and differed markedly from the absence of a gradient for serotonin (reviewed above and see Figure 1).

Within the primary sensory cortex, the noradrenergic innervation shows some laminar specialization, particularly in primates. In the primate somatosensory cortex, noradrenergic fibers are fairly uniform and dense throughout layers (Morrison et al., 1982b; Lewis et al., 1987). The innervation of the primary auditory cortex (Campbell et al., 1987) and primary visual cortex (Kosofsky et al., 1984; Morrison and Foote, 1986), in contrast, is sparser overall, and a "striking absence" (Foote and Morrison, 1987) of layer 4 innervation, particularly in V1, has been observed. Combined with the near absent innervation of the LGN (Morrison and Foote, 1986), which provides the dominant feed-forward visual input to V1, this suggests that - in contrast to the serotonergic system - noradrenergic modulation does not target the visual input stage. Interestingly, such complementarity between the serotonergic and noradrenergic innervation of the sensory input stage is also present in the rat olfactory bulb. While "virtually no label" was observed in the glomerular layer (the 
TABLE 3 | Anatomical findings for the NA system in early sensory areas.

\begin{tabular}{|c|c|c|c|}
\hline Structure & Species & Significance & Reference \\
\hline $\mathrm{V}_{1}$ & Squirrel monkey & Noradrenergic projections preferentially to layers 5 and 6 of $\mathrm{V}_{1}$ & $\begin{array}{l}\text { Morrison et al., } 1982 a \text {; } \\
\text { Lewis et al., } 1987\end{array}$ \\
\hline V1 & Macaca fascicularis & NA innervation much sparser than for $5 \mathrm{HT}$, and least dense in layer $4 \mathrm{C}$ & Kosofsky et al., 1984 \\
\hline V1 & Cynomolgus monkey & $\begin{array}{l}\text { NA fibers less pronounced than } 5 \mathrm{HT} \text {. Weak in layers } 1 \text { and } 2 \text {, and } \\
\text { absent in layer } 4 \mathrm{C} \beta\end{array}$ & Kosofsky et al., 1984 \\
\hline $\mathrm{V}_{1}$ & Rat & Decreasing fronto-occipital gradient of NA & Kehr et al., 1976 \\
\hline LGN & $\begin{array}{l}\text { Squirrel monkeys and } \\
\text { macaca fascicularis }\end{array}$ & Almost no noradrenergic innervation in the LGN & Morrison and Foote, 1986 \\
\hline LGN & Rat & $\begin{array}{l}\text { NA fibers preferentially in the dLGN compared to vLGN and IGL } \\
\text { (compared to } 5 \mathrm{HT} \text { fibers preferentially in the vLGN and IGL) }\end{array}$ & $\begin{array}{l}\text { Papadopoulos and } \\
\text { Parnavelas, } 1990\end{array}$ \\
\hline S1 & Squirrel monkey & Labeling in all layers & $\begin{array}{l}\text { Morrison et al., } 1982 \mathrm{~b} \text {; } \\
\text { Lewis et al., } 1987\end{array}$ \\
\hline S1 & Rhesus monkeys & NA concentration highest in somatosensory cortex, lowest in V1 & Brown et al., 1979 \\
\hline A1 & Macaca fascicularis & $\begin{array}{l}\text { Sparse innervation (substantially less dense than } 5 \mathrm{HT} \text { or Ach), lowest } \\
\text { density in layer } 4\end{array}$ & Campbell et al., 1987 \\
\hline Olfactory bulb & Rat & $\begin{array}{l}\text { Virtually no labeling fibers in the glomerular layer (first input stage) but } \\
\text { fibers preferentially in the internal plexiform, granule cell, and external } \\
\text { plexiform layers }\end{array}$ & McLean et al., 1989 \\
\hline $\mathrm{IC}, \mathrm{CN}$ & Rat & LC heavily innervates both structures & Klepper and Herbert, 1991 \\
\hline
\end{tabular}

site of the first synapse of the olfactory input) using anterograde tracer injections in the LC (McLean et al., 1989), this layer showed the densest serotonergic innervation (McLean and Shipley, 1987) (see above). Instead, pronounced noradrenergic innervation in the rat olfactory bulb was observed for the consecutive processing stages, the internal plexiform, granule, and external plexiform layers (McLean et al., 1989).

\section{Noradrenergic Synapses and Receptors}

Similar to the other monoaminergic systems, noradrenergic neurons in the LC show both tonic and phasic modes of activation [reviewed in Berridge and Waterhouse (2003)]. Their axons have characteristic NA-containing varicosities that can form synapses (e.g., Papadopoulos et al., 1989) and likely have non-synaptic release sites (Callado and Stamford, 2000). Three adrenergic receptor families are expressed in the brain (alpha 1, alpha 2, and beta 1-3), which have characteristic pre- and postsynaptic sites and laminar expression patterns across cortex (Berridge and Waterhouse, 2003). Noradrenaline has the highest affinity for the $\alpha 2$ receptors, intermediate for $\alpha 1$ receptors, and lowest affinity for the $\beta$ adrenergic receptors [reviewed in Ramos and Arnsten (2007)]. In the primate PFC, these differences in affinity have been implicated in differentially modulating cognitive processes as a function of the level of noradrenergic tone (Ramos and Arnsten, 2007). They are likely also an important factor in the substantial diversity in modulation of sensory processing observed for NA (see below).

\section{Noradrenergic Modulation of Sensory Physiology}

The brain's noradrenergic system has long been linked to arousal (e.g., O'Hanlon, 1965; reviewed in, e.g., Berridge and Waterhouse, 2003; Sara and Bouret, 2012) and to adapting network activity for optimal, flexible behavior (Aston-Jones and Cohen, 2005; Bouret and Sara, 2005). Consistent with such a general function, NA has been shown to modulate sensory processing in complex ways (Table 4).

Earlier findings have been reviewed in detail (Berridge and Waterhouse, 2003). In brief, activating the LC or local application of NA has been found to result in a variety of effects, including inhibitory and/or facilitating modulation, selective gating, changes to a neuron's receptive field, and changes to its SNR. For example, iontophoretic application of NA was found to predominantly decrease responses in the dLGN, dorsal, and ventral thalamus of cats (Phillis et al., 1967; Phillis and Teběcis, 1967), in A1 of squirrel monkeys (Foote et al., 1975) and of rats (Manunta and Edeline, 1997), and in rat S1 (Armstrong-James and Fox, 1983; Bassant et al., 1990). Conversely, a predominantly facilitating effect was observed for iontophoretic application of NA or LC stimulation in the rat dLGN (Rogawski and Aghajanian, 1980; Kayama et al., 1982) or V1 (Waterhouse et al., 1990), and for phasic LC stimulation in rat S1 (Waterhouse and Woodward, 1980; Waterhouse et al., 1980, 1998) or rat piriform cortex (Bouret and Sara, 2002). In cat V1 Sato and colleagues (Sato et al., 1989), observed a substantial layerdependence of the response modulation with LC stimulation. It was predominantly inhibitory in layers $2-4$, mostly $\alpha$ receptor mediated facilitation in layer 5 and approximately balanced in both directions in layer 6. These laminar differences likely reflect different receptor expression profiles across layers. The results suggest that some of the variability between studies may also reflect laminar differences between studies within the targeted structures in addition to, e.g., dose-dependent effects. Mirroring this variability, noradrenergic effects on the neuronal SNR differed between studies. While some reported an enhanced SNR (e.g., Foote et al., 1975; Waterhouse and Woodward, 1980; Kasamatsu and Heggelund, 1982) and others (Sato et al., 1989; Manunta and Edeline, 1997) reported no net effect on SNR across the population. In line with the notion of optimizing the 
TABLE 4 | Findings related to sensory modulation by NA.

\begin{tabular}{|c|c|c|c|}
\hline Sensory area & $\begin{array}{l}\text { Species and anesthesia } \\
\text { (if applicable) }\end{array}$ & Significance & Reference \\
\hline dLGN & $\begin{array}{l}\text { Chloral hydrate/urethane } \\
\text { anesthetized rat }\end{array}$ & $\begin{array}{l}\text { NA or LC activation facilitates responses in dLGN; the facilitation } \\
\text { of LGN response to LC stimulation is blocked by } \alpha 1 \text { but not } \beta \\
\text { receptor antagonists }\end{array}$ & $\begin{array}{l}\text { Rogawski and Aghajanian, 1980; } \\
\text { Kayama et al., } 1982\end{array}$ \\
\hline $\begin{array}{l}\text { dLGN, dorsal, and ventral } \\
\text { thalamus }\end{array}$ & Halothane anesthetized cat & $\begin{array}{l}\text { Predominantly depression of responses by iontophoretic } \\
\text { application of NA }\end{array}$ & $\begin{array}{l}\text { Phillis et al., 1967; Phillis and } \\
\text { Teběcis, } 1967\end{array}$ \\
\hline $\mathrm{V}_{1}$ & $\begin{array}{l}\text { Nitrous oxide anesthetized } \\
\text { cat }\end{array}$ & Bi-directional modulation. Enhanced SNR for modulated neurons & Kasamatsu and Heggelund, 1982 \\
\hline V1 & $\begin{array}{l}\text { Halothane } \\
\text { anesthetized/nitrous oxide } \\
\text { cat }\end{array}$ & $\begin{array}{l}\text { LC stimulation results in both facilitation and inhibition of } \\
\text { extracellular responses in } \mathrm{V} 1 \text {, which vary by layer. Results from } \\
\alpha 1, \alpha 2 \text {, and } \beta \text { antagonists suggest that } \alpha \text { receptors facilitate the } \\
\text { responses while } \beta \text { receptor activation results in bi-directional } \\
\text { modulation. No change in SNR }\end{array}$ & Sato et al., 1989 \\
\hline V1 & Thiopental anesthetized cat & $\begin{array}{l}\text { Iontophoretic NA application results in variable modulation of the } \\
\text { responses and affects receptive field properties }\end{array}$ & McLean and Waterhouse, 1994 \\
\hline $\mathrm{V}_{1}$ & Awake mouse & $\begin{array}{l}\text { NA was found necessary for tonic depolarization with locomotion } \\
\text { of layer } 2 / 3 \text { excitatory neurons }\end{array}$ & Polack et al., 2013 \\
\hline V1 & Urethane anesthetized rat & LC activity precedes increases in cortical excitability & Safaai et al., 2015 \\
\hline V1 & Halothane anesthetized rat & Iontophoretic application of NA enhances visual responses & Waterhouse et al., 1990 \\
\hline A1 & Awake squirrel monkey & $\begin{array}{l}\text { lontophoretic NA application decreases evoked and spontaneous } \\
\text { extracellular activity consistent with an increased SNR }\end{array}$ & Foote et al., 1975 \\
\hline A1 & Urethane-anesthetized rat & $\begin{array}{l}\text { Iontophoretic NA application induces bi-directional modulation, } \\
\text { with the dominant effect a response decrease, } \alpha 1 \text {-receptor } \\
\text { mediated. No net change in SNR across the population }\end{array}$ & Manunta and Edeline, 1997 \\
\hline CN & Awake bat & $\begin{array}{l}\text { Enhances "temporal contrast," i.e., the temporal precision of the } \\
\text { response }\end{array}$ & Kössl and Vater, 1989 \\
\hline $\begin{array}{l}\text { S1 and ventral } \\
\text { posteriomedial thalamus }\end{array}$ & Awake rat & $\begin{array}{l}\text { Tonic vs. phasic activation differentially modulates responses in } \\
\text { the somatosensory processing hierarchy }\end{array}$ & Devilbiss and Waterhouse, 2011 \\
\hline S1 & Isoflurane anesthetized rat & $\begin{array}{l}\text { Intracellular recordings in vivo: NA blockage reduces up-states in } \\
\text { neurons }\end{array}$ & Constantinople and Bruno, 2011 \\
\hline S1 & $\begin{array}{l}\text { Urethane anesthetized and } \\
\text { awake rat }\end{array}$ & $\begin{array}{l}\text { Iontophoretic NA application suppresses spontaneous and } \\
\text { glutamate evoked activity }\end{array}$ & $\begin{array}{l}\text { Armstrong-James and Fox, 1983; } \\
\text { Bassant et al., } 1990\end{array}$ \\
\hline S1 & Halothane anesthetized rat & $\begin{array}{l}\text { Variable effects on rates and SNR for iontophoretic NA } \\
\text { application; phasic LC stimulation predominantly enhances } \\
\text { responses. NA depletion abolishes this modulation }\end{array}$ & $\begin{array}{l}\text { Waterhouse and Woodward, } \\
\text { 1980; Waterhouse et al., 1980, } \\
1998\end{array}$ \\
\hline Piriform cortex & Urethane anesthetized rat & $\begin{array}{l}\text { Mainly enhancement of odor responses in piriform cortex with LC } \\
\text { stimulation }\end{array}$ & Bouret and Sara, 2002 \\
\hline Olfactory bulb & Urethane anesthetized rat & $\begin{array}{l}\text { Infusion of NA and stimulation of the LC decreases responses at } \\
\text { low and high levels but not intermediate levels of stimulation/NA }\end{array}$ & Manella et al., 2017 \\
\hline
\end{tabular}

neuronal gain for behavior (Aston-Jones and Cohen, 2005), this variability may reflect the noradrenergic role in different states of a dynamical system.

Indeed, simultaneous recordings in the LC and barrel cortex of anesthetized rats combined with dynamical systems modeling showed that activity in the LC was highly predictive of dynamic changes in cortical excitability (Safaai et al., 2015). Moreover, phasic responses in the LC or urethane anesthetized rats were elicited by aversive somatosensory stimuli and modulated the stimulus-induced gamma oscillations in the mPFC, suggesting a corresponding modulation of somatosensory processing (Neves et al., 2018). In awake mice, visual responses have been found to be substantially enhanced during phases when the animals were running compared to no locomotion (Niell and Stryker, 2010). Intriguingly, intracellular recordings showed that this effect was accompanied by a depolarization of the membrane potential in layer $2 / 3$ neurons, which in turn was blocked by noradrenergic antagonists (Polack et al., 2013). Indeed, both noradrenergic and cholinergic mechanisms were linked to this locomotiondependent modulation, with partially complementary functions (Polack et al., 2013; Reimer et al., 2016). These findings align with the notion of a noradrenergic role in adapting sensory circuits for optimal behavior (Aston-Jones and Cohen, 2005). Additionally, they highlight the importance of interactions between neuromodulatory systems that go beyond the scope of this review.

\section{DOPAMINERGIC MODULATION OF SENSORY PROCESSING}

\section{Dopamine Sources}

Dopamine synthesizing neurons represent a comparatively small population of neurons in the mammalian brain (Bentivoglio 
and Morelli, 2005). The majority of DA neurons are found in three cell groups in the ventral midbrain (mesencephalon) (Dahlström and Fuxe, 1964). Based on cytoarchitectonic features, most dopaminergic cells reside in the substantia nigra (SN) pars compacta (SNc, A9), the ventral tegmental area (VTA, A10) medial to the SN and in the retrorubral area (RRA; A8), which lies caudal and dorsal to the SN. Other, smaller dopaminergic cell groups are present in the periaqueductal gray matter (PAG; A11) and in the hypothalamus (A12-A15), the lateral parabrachial nucleus, the olfactory bulb (A16), and in the retina (A17) (Sánchez-González et al., 2005).

The most frequently used marker for identifying dopaminergic neurons is tyrosine hydroxylase $(\mathrm{TH})$, the rate-limiting enzyme of DA synthesis. For TH-immunopositive neurons, the A8 group comprises approx. 5\% of cells, while A9 and $\mathrm{A} 10$ account for the remaining $95 \%$ with a slight dominance of A9 over A10 (Bentivoglio and Morelli, 2005). The DA system undergoes considerable expansion from rodents to primates (Berger et al., 1991). By immunostaining for TH, the number of mesencephalic DA neurons has been estimated at approx. 20,000-30,000 in total in mice (Nelson et al., 1996), 45,000 in rats (German and Manaye, 1993), 110,000-220,000 in the SN in rhesus monkeys (Emborg et al., 1998), and between 230,000 and 430,000 in the human SN (Chu et al., 2002). Thus, a large dopaminergic A9 group is a distinctive feature of the primate brain.

Tyrosine hydroxylase labeling to identify dopaminergic neurons has been called into question because of a lack of specificity (Lammel et al., 2015). Staining for the dopamine transporter (DAT), which removes DA from the extracellular space and is largely responsible for the termination of dopaminergic neurotransmission, is more specific and is not detected, e.g., in noradrenergic cells (Ciliax et al., 1995). However, DAT is not expressed in all DA neurons. For example, it cannot be used to label the diencephalic (hypothalamic) cell groups (Sánchez-González et al., 2005). The subgroup of VTA DA neurons that project to the PFC also contains very little DAT (Lammel et al., 2008). Distinct expression profiles of $\mathrm{TH}$ and DAT can therefore be exploited to trace independent populations among dopaminergic neurons.

There is mounting evidence that DA is also released from terminals of LC neurons as a co-transmitter of NA (Devoto et al., 2001, 2003, 2005). These important findings underscore the potential caveats of using cellular protein markers instead of the transmitter receptor or the transmitter itself to investigate monoaminergic neurotransmission. Considerable complexity within the monoaminergic system is therefore likely to shape sensory and higher-order cognitive processing (Takeuchi et al., 2016).

\section{Dopamine Projections}

A variety of different techniques has been used to investigate dopaminergic innervation of target structures, including direct (e.g., photometric or autoradiographic) neurotransmitter measurements (Brown et al., 1979; Descarries et al., 1987), immunostaining for $\mathrm{TH}$ in comparison to staining for DA- $\beta$ hydroxylase (Lewis et al., 1987) and DAT (Sánchez-González et al., 2005), DA receptor autoradiography (Lidow et al., 1991), and DA receptor mRNA assays (Weiner et al., 1991; Hurd et al., 2001; Santana et al., 2009). It is important to keep in mind that these methods differ not just with regard to their sensitivity and specificity, but that they also target distinct stages of DA production and neurotransmission. This is a likely source of variability and even discrepancy in the literature. Ultimately, functional evidence is required that local DA modulates neuronal processing in target areas. Physiological studies are therefore the gold-standard for demonstrating effective dopaminergic innervation (see below).

The DA system projects extensively to many subcortical and cortical structures of the brain, albeit with a clear concentration. Lewis et al. (1987) noted, summarizing their work on the cortical distribution of dopaminergic afferents in the non-human primate, that "dopaminergic fibers preferentially innervate motor over sensory regions, sensory association over primary sensory regions, and auditory association over visual association regions."

The dopaminergic projections from the midbrain are typically subdivided into the mesostriatal pathway and the mesocorticolimbic pathway. The striatum is the major target of mesencephalic DA neurons (Bentivoglio and Morelli, 2005). Ipsilateral projections to the dorsal striatum mainly arise from the SNc (nigrostriatal pathway). Limbic efferents including projections to the ventral striatum (nucleus accumbens) emanate largely from the VTA.

The mesocortical pathways target in particular the motor cortex, the prefrontal, the anterior cingulate, and the rhinal cortices in rodents (Descarries et al., 1987) and in the nonhuman primate (Berger et al., 1988; Lidow et al., 1991). Similar to the number of dopaminergic midbrain neurons, however, the density of cortical DA terminals varies considerably from species to species, reaching a maximum in primates (Berger et al., 1991). Unlike NA and, especially, serotonin, cortical levels of DA in the macaque brain exhibit a prominent gradient with a strong decrease along the fronto-occipital axis and only minimal amounts detectable in visual cortex (Brown et al., 1979; see Figure 1B).

Mesocortical projections originate from all major cell groups in the ventral mesencephalon, with a looser organization compared to the mesostriatal system. A clear topographical relationship, however, has been described for the most densely innervated frontal lobe. Dopaminergic projections to the dorsolateral PFC in the macaque brain arise from the dorsal and lateral regions of three midbrain cell groups A8, A9, and A10, whereas the ventromedial regions of the PFC receive projections from the medial parabrachial pigmented nucleus and the midline nuclei of the VTA (Williams and Goldman-Rakic, 1998). A similar medial-lateral arrangement has been found in rats (Loughlin and Fallon, 1984). Here, most of the dopaminergic innervation of the medial frontal cortex comes from VTA neurons that project to the deep layers 5 and 6 of the mPFC and in particular to the orbitofrontal cortex (Chandler et al., 2013), with substantially fewer cells from the SNc innervating predominately the superficial mPFC layers (Berger et al., 1991). SNc DA neurons preferentially target the lateral frontal cortex, e.g., the premotor areas (Loughlin and Fallon, 1984; Muller et al., 2014). 
Overall, VTA dopaminergic neurons show little collateralization to extensive terminal fields, somewhat in contrast to SNc cells (Loughlin and Fallon, 1984; Chandler et al., 2013). This suggests that, in light of the topographical arrangement described above, discrete, anatomically circumscribed dopaminergic subsystems exist that could modulate selected target regions.

\section{Dopamine Synapses and Receptors}

Dopamine-containing varicosities can form multiple synaptic contacts along the course of an axonal fiber. In frontal cortex, these terminals establish conventional, symmetric synapses with postsynaptic dendritic shafts and spines, preferentially on pyramidal neurons (Berger et al., 1991). At the ultrastructural level, dopaminergic afferents form synaptic triads with postsynaptic spines that receive a second, presumably glutamatergic input (Goldman-Rakic et al., 1989). This configuration would allow DA to modulate ongoing neuronal transmission both pre- and postsynaptically.

Dopamine receptors are expressed by pyramidal neurons and GABAergic interneurons alike, indicating that DA modulates excitatory and inhibitory synaptic transmission (Santana et al., 2009). Dopamine receptors are categorized into two major families: the $\mathrm{D} 1$ family comprising the $\mathrm{D}_{1}$ and $\mathrm{D}_{5}$ receptors, and the $\mathrm{D} 2$ family comprising the $\mathrm{D}_{2}, \mathrm{D}_{3}$, and $\mathrm{D}_{4}$ receptors. Both $\mathrm{D} 1$ and D2 families of receptors are $\mathrm{G}$ protein-coupled receptors, which initiate intracellular signaling cascades rather than directly inducing postsynaptic currents (Missale et al., 1998; Bentivoglio and Morelli, 2005). D1 and D2 receptors are largely expressed in different cell populations (Vincent et al., 1993). In most rat brain structures except for the VTA and some midbrain cell groups, D1 receptors outnumber D2 receptors (Boyson et al., 1986; Weiner et al., 1991). In the human brain, D1 receptor mRNA clearly dominates over D2 receptor mRNA in the cortical mantle, whereas D2 receptor mRNA is more abundant in the hippocampal formation, brainstem, and in subcortical structures such as the thalamus (Hurd et al., 2001). Of note, a high proportion of DA (D1) receptors are found at extrasynaptic sites, suggesting that DA might also exert its effects via diffusion in the neuropil (volume transmission) (Smiley et al., 1994).

Cortical DA receptors show a laminar-specific distribution profile. D1 receptors are expressed in all cortical layers in the primate frontal brain (Lidow et al., 1991; Huntley et al., 1992), often with a bilaminar infra-supragranular pattern with a relative paucity in layer 4 (Lewis et al., 1987) and a predilection for deeper layers. D2 receptors, in contrast, are typically confined to cortical layer 5 (Weiner et al., 1991; Lidow et al., 1998).

\section{Dopaminergic Innervation of Sensory Brain Structures}

Compared to the densely innervated frontal cortex, the sensory cortices receive very sparse dopaminergic afferents (Table 5). In both rat and primate studies, the primary visual cortex shows the lowest DA fiber density of all investigated cortical structures (Descarries et al., 1987; Lidow et al., 1991). TH immunoreactivity in primate primary visual cortex $\mathrm{V} 1$ is restricted to layer 1 , and few fibers reach layer 6 as well in V2 (Lewis et al., 1987; Berger et al., 1988). The same layers are targeted by dopaminergic fibers in the rat primary visual cortex (Phillipson et al., 1987).

A slight increase in fiber density is seen in primary auditory cortex. In the gerbil, D1 receptors are found in infragranular layers mainly associated with pyramidal neurons (Schicknick et al., 2008). TH positive fibers loosely innervate auditory cortex layers 1 and 6 in primates (Lewis et al., 1987). In primary somatosensory cortex, labeled fibers are also found in layer 5. A further increase in dopaminergic innervation is then observed in the association cortices of the temporal, parietal, and frontal lobe, where the aforementioned bilaminar profile emerges (Lewis et al., 1987).

Dopaminergic fibers have also been reported to innervate subcortical structures that are involved in processing sensory stimuli. Dopamine axons reach the LGN of the thalamus (LGN, visual nucleus) (Papadopoulos and Parnavelas, 1990). Here, D1 and D2 receptors are found in excitatory relay neurons and in inhibitory local interneurons (Albrecht et al., 1996; Zhao et al., 2002; Munsch et al., 2005). D2 receptors are also present in the thalamic medial geniculate nucleus (MGN, auditory nucleus) (Hurd et al., 2001; Chun et al., 2014) and in the ventrobasal complex (VB, somatosensory nucleus) (Govindaiah et al., 2010b).

While these first-order thalamic nuclei mainly relay sensory input to the cortex, the second-order thalamic nuclei are part of cortico-thalamo-cortical loops and could support higher brain functions operating on sensory information (Sherman, 2016). The second-order thalamus is more strongly innervated by DA neurons than its first-order counterpart, reaching the levels of highest cortical density in some nuclei (Sánchez-González et al., 2005). Thalamic DA fibers are much denser in primates than in rodents (García-Cabezas et al., 2009). Dopaminergic afferents in the thalamus stem from multiple sources including the hypothalamus, ventral mesencephalon, the PAG, and the lateral parabrachial nucleus, possibly hinting at the existence of a distinct "thalamic dopaminergic system" (Groenewegen, 1988; Sánchez-González et al., 2005). Interestingly, the densest dopaminergic projections to the thalamus are found in those second-order nuclei that are linked to frontal and limbic cortex, e.g., the mediodorsal (MD) nucleus and the midline nuclei (García-Cabezas et al., 2007). In fact, these DA projections share many anatomical features with the strong meso-prefrontal DA system (Melchitzky et al., 2006). These findings suggest that DA could modulate higher-order frontal lobe functions both at the cortical level and by controlling its associated thalamic nuclei (Varela, 2014). Finally, it has been noted that VTA axon terminals and terminals from thalamic MD neurons converge in $\mathrm{mPFC}$ layer 5, forming a synaptic triad as described above (Kuroda et al., 1996). Thus, dopaminergic modulation of thalamic function might also have extra-thalamic components.

The main auditory midbrain nucleus, the IC, is targeted by $\mathrm{TH}$-immunoreactive nerve terminals arising from the subparafascicular thalamic nucleus (Tong et al., 2005; Nevue et al., 2015), and the IC has been shown to express D2 receptors (Weiner et al., 1991). Dopaminergic afferents to the superior colliculus, a crucial midbrain structure for oculomotor and visual processing, are sparser in comparison (Weiner et al., 1991). 
TABLE 5 | Anatomical findings for the DA system in early sensory areas.

\begin{tabular}{|c|c|c|c|}
\hline Structure & Species & Significance & Reference \\
\hline V1 & Rhesus monkey and rat & Lowest density of dopaminergic innervation across cortical mantle & $\begin{array}{l}\text { Brown et al., 1979; Descarries } \\
\text { et al., 1987; Lidow et al., } 1991\end{array}$ \\
\hline V1 & Cynomolgus monkey & TH immunoreactive fibers restricted to layer 1 & Berger et al., 1988 \\
\hline V1 & Rat & Dopaminergic innervation in infragranular layers and weaker in layer 1 & Phillipson et al., 1987 \\
\hline A1 & Gerbil & D1 receptors in infragranular layers & Schicknick et al., 2008 \\
\hline A1 & $\begin{array}{l}\text { Cynomolgus and squirrel } \\
\text { monkey }\end{array}$ & TH immunoreactive fibers in layers 1 and 6 & Lewis et al., 1987 \\
\hline S1 & $\begin{array}{l}\text { Cynomolgus and squirrel } \\
\text { monkey }\end{array}$ & TH immunoreactive fibers in supra- and infragranular layers & Lewis et al., 1987 \\
\hline LGN & Rat & Dopaminergic innervation of all LGN subdivisions & $\begin{array}{l}\text { Papadopoulos and Parnavelas, } \\
1990\end{array}$ \\
\hline LGN and MGN & Human & Moderate levels of D2 receptor mRNA & Hurd et al., 2001 \\
\hline Inferior colliculus & Rat and mouse & Innervation by $\mathrm{TH}$ immunoreactive fibers & $\begin{array}{l}\text { Tong et al., 2005; Nevue et al., } \\
2015\end{array}$ \\
\hline Inferior colliculus & Rat & D2 receptors present at moderate levels & Weiner et al., 1991 \\
\hline Superior colliculus & Rat & D2 receptors present at low levels & Weiner et al., 1991 \\
\hline
\end{tabular}

TABLE 6 | Findings related to sensory modulation by DA.

\begin{tabular}{|c|c|c|c|}
\hline Structure & $\begin{array}{l}\text { Species and anesthesia (if } \\
\text { applicable) }\end{array}$ & Significance & Reference \\
\hline V1 & $\begin{array}{l}\text { Remifentanil anesthetized } \\
\text { rhesus monkey }\end{array}$ & $\begin{array}{l}\text { Systemic administration of L-DOPA increases supragranular oscillatory } \\
\text { activity encoding visual information, but failure to induce changes in } \\
\text { neuronal activity by local DA application }\end{array}$ & Zaldivar et al., 2018, 2014 \\
\hline dLGN & $\begin{array}{l}\text { Urethane anesthetized rat and } \\
\text { ketamine or halothane } \\
\text { anesthetized cat }\end{array}$ & $\begin{array}{l}\text { D1 receptors inhibit and D2 receptors excite extracellularly recorded } \\
\text { relay neurons }\end{array}$ & $\begin{array}{l}\text { Phillis et al., 1967; Albrecht } \\
\text { et al., 1996; Zhao et al., } 2002\end{array}$ \\
\hline dLGN & Rat and mouse (brain slices) & $\begin{array}{l}\text { D1 receptors depolarize and D2 receptors inhibit intracellularly recorded } \\
\text { neurons }\end{array}$ & $\begin{array}{l}\text { Govindaiah and Cox, 2005; } \\
\text { Munsch et al., } 2005\end{array}$ \\
\hline A1 & Awake gerbil & D1 receptors modulate auditory discrimination learning & $\begin{array}{l}\text { Schicknick et al., 2012; Happel } \\
\text { et al., } 2014\end{array}$ \\
\hline MGN & Mouse (brain slices) & $\begin{array}{l}\text { D2 receptors modulate synaptic transmission at thalamocortical } \\
\text { afferents in } A 1\end{array}$ & Chun et al., 2014 \\
\hline Inferior colliculus & Awake mouse & Dopamine inhibits neuronal activity & Gittelman et al., 2013 \\
\hline S1 & Awake rat & Dopamine inhibits neuronal activity & Bassant et al., 1990 \\
\hline Ventrobasal thalamus & Rat (brain slices) & Dopamine increases excitability of intracellularly recorded neurons & Govindaiah et al., 2010a \\
\hline
\end{tabular}

\section{Dopaminergic Modulation of Sensory Physiology}

Dopamine neuron activity is classically described as being time locked to the presentation of rewarding stimuli. Phasic firing of action potentials by DA neurons especially in the medial mesencephalon communicates a reward prediction error that scales with the difference between predicted and actual reward (Schultz, 2007). These neurophysiological findings form the basis for the large number of studies that have investigated DA's role in motivation, appetence, and reward-related learning ("motivational salience"). More recent experiments have revealed the existence of functionally distinct subgroups of DA neurons in particular in the lateral midbrain that are activated both by rewarding and aversive events (Matsumoto and Hikosaka, 2009; Matsumoto et al., 2013). This suggests that these neurons are responsive to a more general group of sensory stimuli that are behaviorally relevant and should trigger an appropriate coordinated response ("cognitive salience"). The physiological effects of DA on sensory information processing, however, are not yet well understood. Given the sparse innervation of sensory structures, comparatively few studies have addressed the role of DA in directly modulating sensory inputs (Table 6).

In rat and cat dorsal LGN, in vivo iontophoretic activation of D1 receptors produced inhibition, whereas engagement of D2 receptors resulted in excitation of extracellularly recorded relay neurons (Phillis et al., 1967; Albrecht et al., 1996; Zhao et al., 2002). Intracellular recordings in rat and mouse LGN slices, however, found that D1 receptors lead to an excitatory membrane depolarization in relay neurons (Govindaiah and Cox, 2005), whereas D2 receptors on local GABAergic interneurons produced inhibition in postsynaptic neurons (Munsch et al., 2005), in complete contrast to the in vivo results. It is currently unclear whether these diverging findings reflect dose-dependent effects, where application of small and large drug concentrations often yields opposite effects (Zhao et al., 2002), or rather result from 
network mechanisms that differ in the in vivo and in vitro preparation.

In primate primary visual cortex (V1), oscillatory activity (local field potentials) containing information about animated visual stimuli (movie clips) was enhanced in particular in supragranular layers following systemic administration of the DA precursor L-DOPA (Zaldivar et al., 2018). However, focal application of DA failed to induce changes in neuronal activity (Zaldivar et al., 2014), possibly reflecting the very sparse dopaminergic innervation of the occipital pole. In accordance with the notion that dopaminergic effects on visual processing are not mediated by early primary visual regions but possibly by higher-order brain areas, visually induced neuronal responses were directly modulated by DA in the monkey lateral PFC (Jacob et al., 2013). Here, iontophoretically applied DA affected two distinct neuronal populations involved in encoding behaviorally relevant visual stimuli. In putative interneurons, DA inhibited activity in form of a subtractive shift in response levels with unchanged SNR. In putative pyramidal neurons, DA increased excitability in form of a multiplication in gain and enhanced SNR through a reduction of response variability across trials (Jacob et al., 2013). By increasing the coding strength of sensory signals, DA could play a crucial role in how sensory information is represented, memorized, and interpreted in PFC (Ott et al., 2014; Jacob et al., 2016).

Acting on cognitive brain centers, DA might influence visual cortical processing (Arsenault et al., 2013) by longrange interactions originating, e.g., in frontal cortex. Support for this hypothesis comes from exploring DA's modulatory influence on PFC-guided allocation of visual attention in the macaque monkey (Noudoost and Moore, 2011). D1R were blocked by local antagonist injections into sites of the frontal eye fields (FEFs) that represented the same region of visual space (the "response field") as simultaneously recorded neurons in visual cortex area V4. Prefrontal D1R antagonism caused the animals to saccade more frequently toward FEF response field targets, meaning this part of the visual field had grasped their attention. The response properties of V4 neurons were changed in a way that is consistent with a multiplicative increase in gain: first, there was an enhancement in the magnitude of responses to visual stimulation; second, the visual responses became more selective to stimulus orientation; third, the visual responses became less variable across trials (Noudoost and Moore, 2011). Thus, prefrontal top-down control over visual cortical neurons during visual attention is under the influence of D1 receptors.

In the auditory system, both inhibitory and - less frequently excitatory responses in IC neurons were observed after local iontophoretic application of DA in awake mice (Gittelman et al., 2013). The importance of subcortical DA for auditory information processing was underscored by showing that overexpressed MGN D2 receptors in a schizophrenia mouse model reduce the efficiency of synaptic transmission of excitatory thalamocortical afferents in auditory cortex (Chun et al., 2014). These changes were accompanied by behavioral deficits in auditory perception (acoustic startle response). Because thalamocortical afferents in visual or somatosensory cortex were not affected, studying this mouse model might help to provide a neuronal mechanism that links dopaminergic dysfunction to the generation of auditory hallucinations in schizophrenia (Chun et al., 2014). Auditory processing is modulated by cortical DA receptors as well. Systemic administration of D1 receptor antagonists or local injections directly into auditory cortex of gerbils impaired discrimination learning of acoustic stimuli, while D1 receptor agonists improved the animals' performance (Schicknick et al., 2012; Happel et al., 2014).

Finally, the representation of somatosensory information is also strengthened by DA: in vivo depletion of DA in mouse striatum worsened the laterality coding of whisker deflections in medium spiny neurons, i.e., the projection neurons of this structure, indicating that tactile acuity requires dopaminergic input (Ketzef et al., 2017). Intracellular recordings in rat VB thalamic slices showed that DA increases neuronal excitability in two different ways: activation of $\mathrm{D} 1$ receptors leads to membrane depolarization, whereas D2 receptors facilitate action potential discharge (Govindaiah et al., 2010b). In contrast, in rat S1, iontophoretic DA application produced inhibitory effects on neuronal firing (Bassant et al., 1990).

\section{Putting It All Together: Monoaminergic Neuromodulation of Sensory Processing}

The discussed studies provide compelling evidence that the representation and processing of sensory information is heavily regulated by the brain's monoamine transmitters. Despite their widespread cortical and subcortical targeting, the monoaminergic systems are by no means blurry, brain-wide modulators of neuronal activity. They send regionally and laminar-specific projections, which may allow them to control both feed-forward and feed-back influences (Cumming and Nienborg, 2016) on sensory signaling by distinct mechanisms. These regional and laminar differences are particularly pronounced in the macaque brain (Figure 1).

The indolamine serotonin has prominent projections to the primary sensory areas and innervates all cortical layers including the thalamo-cortical input layer 4. Serotonin is well suited to regulate the sensory input stages by acting in these primary sensory areas and in the first-order thalamic relay nuclei. Despite some degree of variability between studies on the serotonergic modulation of sensory processing, the emerging pattern is that it dampens neuronal responses and reduces gain. The reduction in gain may reduce the salience of a sensory stimulus (Seillier et al., 2017). Alternatively, if it only affects the spontaneous but not the stimulus-driven response (Lottem et al., 2016), it may increase a neuron's SNR and hence effectively increase stimulus salience. Probing the serotonergic modulation of sensory processing during perceptually driven behavior may resolve this seeming discrepancy. In general, however, the experimental data show that serotonin directly modulates sensory processing as early as the feed-forward sensory input stage. 
In contrast to serotonin the catecholamine DA has a pronounced fronto-occipital gradient (Figure 1), is less abundant in sensory cortices, particularly sparse in the primary visual cortex, and only weakly active in granular layers. This suggests that dopaminergic effects on sensory processing are not mediated primarily by local modulation of early sensory input stages (e.g., Zaldivar et al., 2014) but instead by modulating longrange recurrent cortico-cortical and cortico-bulbar interactions originating in the strongly innervated supragranular and infragranular layers, respectively, e.g., of the frontal lobe cognitive control centers (Lewis et al., 1987; Noudoost and Moore, 2011; Jacob et al., 2013). Its modulatory effects stem from a variable and complex combination of inhibition and excitation in the targeted circuits. The net result is likely an increase in SNR, which is based both on additive operations, e.g., predominant suppression of responses to non-preferred stimuli ("sculpting inhibition") (Vijayraghavan et al., 2007), and on multiplicative operations, e.g., increase in gain and response reliability (reduction of trialto-trial variability) (Noudoost and Moore, 2011; Jacob et al., 2013). Thus, the role of DA could primarily be to adapt the readout of sensory circuits to best serve task demands and behavioral goals.

The catecholamine NA, conversely, may play a role in between these two extremes. It has a less pronounced frontooccipital gradient than DA and, like serotonin, substantial projections to the primary sensory cortices, including the primary visual cortex. But in contrast to serotonin, the innervation of the granular layers is relatively sparse (Figure 1). The modulatory effects of NA on sensory processing are diverse. This variability may reflect adaptable modulation depending on the behavioral state of the animal, in line with the notion of optimizing the neuronal gain for behavior (Aston-Jones and Cohen, 2005).

\section{REFERENCES}

Albrecht, D., Quäschling, U., Zippel, U., and Davidowa, H. (1996). Effects of dopamine on neurons of the lateral geniculate nucleus: an iontophoretic study. Synapse 23, 70-78. doi: 10.1002/(SICI)1098-2396(199606)23:2<70::AIDSYN2>3.0.CO;2-D

Armstrong-James, M., and Fox, K. (1983). Effects of ionophoresed noradrenaline on the spontaneous activity of neurones in rat primary somatosensory cortex. J. Physiol. 335, 427-447. doi: 10.1113/jphysiol.1983.sp014542

Arsenault, J. T., Nelissen, K., Jarraya, B., and Vanduffel, W. (2013). Dopaminergic reward signals selectively decrease fMRI activity in primate visual cortex. Neuron 77, 1174-1186. doi: 10.1016/j.neuron.2013.01.008

Aston-Jones, G., and Cohen, J. D. (2005). Adaptive gain and the role of the locus coeruleus-norepinephrine system in optimal performance. J. Comp. Neurol. 493, 99-110. doi: 10.1002/cne.20723

Bassant, M. H., Ennouri, K., and Lamour, Y. (1990). Effects of iontophoretically applied monoamines on somatosensory cortical neurons of unanesthetized rats. Neuroscience 39, 431-439. doi: 10.1016/0306-4522(90)90279-D

Beaudet, A., and Descarries, L. (1976). Quantitative data on serotonin nerve terminals in adult rat neocortex. Brain Res. 111, 301-309. doi: 10.1016/00068993(76)90775-7

Bentivoglio, M., and Morelli, M. (2005). "Chapter I The organization and circuits of mesencephalic dopaminergic neurons and the distribution of dopamine receptors in the brain," in Dopamine: Handbook of Chemical Neuroanal, Vol. 21, eds S. B. Dunnett, M. Bentivoglio, A. Bjorklund, and T. Hokfelt (Amsterdam: Elsevier), 1-107. doi: 10.1016/S0924-8196(05)80005-3
Taken together, the current literature argues for a prominent complementarity in sensory neuromodulation by monoamines. This complementarity is prominent anatomically (Figure 1B), resulting in both direct bottom-up and indirect top-down control over sensory signaling by the indolamine serotonin and the catecholamines NA and DA, respectively (Papadopoulos and Parnavelas, 1991). One of the main challenges will now be to dissect the individual contributions of the anatomically and functionally separable monoamine subsystems in shaping how sensory information is represented, processed, and evaluated by the brain's sensory, cognitive, and motivational networks (Figure 1A). We believe that key to such insights will be the combination of increased specificity and precision when targeting these neuromodulatory systems with well characterized behavior (Krakauer et al., 2017).

\section{AUTHOR CONTRIBUTIONS}

All authors listed have made a substantial, direct and intellectual contribution to the work, and approved it for publication.

\section{FUNDING}

SJ acknowledges support by the German Research Foundation (DFG JA1999/3-1), the German Federal Ministry of Education and Research (01ZX1404C) and the Berlin Institute of Health (TRG 1.2.4). HN acknowledges support by a Starting Independent Researcher Grant from the European Research Council (NEUROOPTOGEN), and by funds from the German Research Foundation awarded to the Centre for Integrative Neuroscience (DFG EXC 307).

Berger, B., Gaspar, P., and Verney, C. (1991). Dopaminergic innervation of the cerebral cortex: unexpected differences between rodents and primates. Trends Neurosci. 14, 21-27. doi: 10.1016/0166-2236(91)90179-X

Berger, B., Trottier, S., Verney, C., Gaspar, P., and Alvarez, C. (1988). Regional and laminar distribution of the dopamine and serotonin innervation in the macaque cerebral cortex: a radioautographic study. J. Comp. Neurol. 273, 99-119. doi: 10.1002/cne.902730109

Berridge, C. W., and Waterhouse, B. D. (2003). The locus coeruleus-noradrenergic system: modulation of behavioral state and state-dependent cognitive processes. Brain Res. Brain Res. Rev. 42, 33-84. doi: 10.1016/S0165-0173(03) 00143-7

Bouret, S., and Sara, S. J. (2002). Locus coeruleus activation modulates firing rate and temporal organization of odour-induced single-cell responses in rat piriform cortex. Eur. J. Neurosci. 16, 2371-2382. doi: 10.1046/j.1460-9568.2002. 02413.x

Bouret, S., and Sara, S. J. (2005). Network reset: a simplified overarching theory of locus coeruleus noradrenaline function. Trends Neurosci. 28, 574-582. doi: 10.1016/j.tins.2005.09.002

Boyson, S. J., McGonigle, P., and Molinoff, P. B. (1986). Quantitative autoradiographic localization of the D1 and D2 subtypes of dopamine receptors in rat brain. J. Neurosci. 6, 3177-3188. doi: 10.1523/JNEUROSCI.06-11-03177. 1986

Brown, R. M., Crane, A. M., and Goldman, P. S. (1979). Regional distribution of monoamines in the cerebral cortex and subcortical structures of the rhesus monkey: concentrations and in vivo synthesis rates. Brain Res. 168, 133-150. doi: 10.1016/0006-8993(79)90132-X 
Callado, L. F., and Stamford, J. A. (2000). Spatiotemporal interaction of alpha(2) autoreceptors and noradrenaline transporters in the rat locus coeruleus: implications for volume transmission. J. Neurochem. 74, 2350-2358. doi: 10.1046/j.1471-4159.2000.0742350.x

Campbell, M. J., Lewis, D. A., Foote, S. L., and Morrison, J. H. (1987). Distribution of choline acetyltransferase-, serotonin-, dopamine-beta-hydroxylase-, tyrosine hydroxylase-immunoreactive fibers in monkey primary auditory cortex. J. Comp. Neurol. 261, 209-220. doi: 10.1002/cne.902610204

Chandler, D. J., Gao, W. J., and Waterhouse, B. D. (2014). Heterogeneous organization of the locus coeruleus projections to prefrontal and motor cortices. Proc. Natl. Acad. Sci. U.S.A. 111, 6816-6821. doi: 10.1073/pnas.1320827111

Chandler, D. J., Lamperski, C. S., and Waterhouse, B. D. (2013). Identification and distribution of projections from monoaminergic and cholinergic nuclei to functionally differentiated subregions of prefrontal cortex. Brain Res. 1522, 38-58. doi: 10.1016/j.brainres.2013.04.057

Chu, Y., Kompoliti, K., Cochran, E. J., Mufson, E. J., and Kordower, J. H. (2002). Age-related decreases in Nurr1 immunoreactivity in the human substantia nigra. J. Comp. Neurol. 450, 203-214. doi: 10.1002/cne.10261

Chun, S., Westmoreland, J. J., Bayazitov, I. T., Eddins, D., Pani, A. K., Smeyne, R. J., et al. (2014). Specific disruption of thalamic inputs to the auditory cortex in schizophrenia models. Science 344, 1178-1182. doi: 10.1126/science.125 3895

Ciliax, B. J., Heilman, C., Demchyshyn, L. L., Pristupa, Z. B., Ince, E., Hersch, S. M., et al. (1995). The dopamine transporter: immunochemical characterization and localization in brain. J. Neurosci. 15(3 Pt 1), 1714-1723. doi: 10.1523/ JNEUROSCI.15-03-01714.1995

Cohen, J. Y., Amoroso, M. W., and Uchida, N. (2015). Serotonergic neurons signal reward and punishment on multiple timescales. eLife 4:e06346. doi: 10.7554/ eLife.06346

Constantinople, C. M., and Bruno, R. M. (2011). Effects and mechanisms of wakefulness on local cortical networks. Neuron 69, 1061-1068. doi: 10.1016/j. neuron.2011.02.040

Costa, V. D., Kakalios, L. C., and Averbeck, B. B. (2016). Blocking serotonin but not dopamine reuptake alters neural processing during perceptual decision making. Behav. Neurosci. 130, 461-468. doi: 10.1037/bne0000162

Cumming, B. G., and Nienborg, H. (2016). Feedforward and feedback sources of choice probability in neural population responses. Curr. Opin. Neurobiol. 37, 126-132. doi: 10.1016/j.conb.2016.01.009

Dahlström, A., and Fuxe, K. (1964). Localization of monoamines in the lower brain stem. Experientia 20, 398-399. doi: 10.1007/BF02147990

Davis, M., Strachan, D. I., and Kass, E. (1980). Excitatory and inhibitory effects of serotonin on sensorimotor reactivity measured with acoustic startle. Science 209, 521-523. doi: 10.1126/science.7394520

Dayan, P., and Huys, Q. (2015). Serotonin's many meanings elude simple theories. eLife 4:e07390. doi: 10.7554/eLife.07390

de Lima, A. D., Bloom, F. E., and Morrison, J. H. (1988). Synaptic organization of serotonin-immunoreactive fibers in primary visual cortex of the macaque monkey. J. Comp. Neurol. 274, 280-294. doi: 10.1002/cne.902740211

DeFelipe, J., Arellano, J. I., Gómez, A., Azmitia, E. C., and Muñoz, A. (2001). Pyramidal cell axons show a local specialization for GABA and 5-HT inputs in monkey and human cerebral cortex. J. Comp. Neurol. 433, 148-155. doi: $10.1002 /$ cne. 1132

DeFelipe, J., Hendry, S. H., Hashikawa, T., and Jones, E. G. (1991). Synaptic relationships of serotonin-immunoreactive terminal baskets on GABA neurons in the cat auditory cortex. Cereb. Cortex 1, 117-133. doi: 10.1093/cercor/ 1.2.117

DeFelipe, J., and Jones, E. G. (1988). A light and electron microscopic study of serotonin-immunoreactive fibers and terminals in the monkey sensory-motor cortex. Exp. Brain Res. 71, 171-182. doi: 10.1007/BF0024 7532

Descarries, L., Lemay, B., Doucet, G., and Berger, B. (1987). Regional and laminar density of the dopamine innervation in adult rat cerebral cortex. Neuroscience 21, 807-824. doi: 10.1016/0306-4522(87)90038-8

Descarries, L., Riad, M., and Parent, M. (2010). "Ultrastructure of the serotonin innervation in the mammalian central nervous system," in Handbook of the Behavioral Neurobiology of Serotonin, eds C. P. Mueller and B. L. Jacobs (London: Academic Press), 82-119.
Devilbiss, D. M., and Waterhouse, B. D. (2011). Phasic and tonic patterns of locus coeruleus output differentially modulate sensory network function in the awake rat. J. Neurophysiol. 105, 69-87. doi: 10.1152/jn.00445.2010

Devoto, P., Flore, G., Longu, G., Pira, L., and Gessa, G. L. (2003). Origin of extracellular dopamine from dopamine and noradrenaline neurons in the medial prefrontal and occipital cortex. Synapse 50, 200-205. doi: 10.1002/syn. 10264

Devoto, P., Flore, G., Pani, L., and Gessa, G. L. (2001). Evidence for co-release of noradrenaline and dopamine from noradrenergic neurons in the cerebral cortex. Mol. Psychiatry 6, 657-664. doi: 10.1038/sj.mp.4000904

Devoto, P., Flore, G., Saba, P., Fà, M., and Gessa, G. L. (2005). Stimulation of the locus coeruleus elicits noradrenaline and dopamine release in the medial prefrontal and parietal cortex. J. Neurochem. 92, 368-374. doi: 10.1111/j.14714159.2004.02866.x

Dori, I., Dinopoulos, A., Blue, M. E., and Parnavelas, J. G. (1996). Regional differences in the ontogeny of the serotonergic projection to the cerebral cortex. Exp. Neurol. 138, 1-14. doi: 10.1006/exnr.1996.0041

Dori, I. E., Dinopoulos, A., and Parnavelas, J. G. (1998). The development of the synaptic organization of the serotonergic system differs in brain areas with different functions. Exp. Neurol. 154, 113-125. doi: 10.1006/exnr.1998.6937

Doty, R. W. (1983). Nongeniculate afferents to striate cortex in macaques. J. Comp. Neurol. 218, 159-173. doi: 10.1002/cne.902180204

Dugué, G. P., Lörincz, M. L., Lottem, E., Audero, E., Matias, S., Correia, P. A., et al. (2014). Optogenetic recruitment of dorsal raphe serotonergic neurons acutely decreases mechanosensory responsivity in behaving mice. PLoS One 9:e105941. doi: 10.1371/journal.pone.0105941

Ebert, U., and Ostwald, J. (1992). Serotonin modulates auditory information processing in the cochlear nucleus of the rat. Neurosci. Lett. 145, 51-54. doi: 10.1016/0304-3940(92)90201-H

Ecker, A. S., Berens, P., Cotton, R. J., Subramaniyan, M., Denfield, G. H., Cadwell, C. R., et al. (2014). State dependence of noise correlations in macaque primary visual cortex. Neuron 82, 235-248. doi: 10.1016/j.neuron.2014.02.006

Emborg, M. E., Ma, S. Y., Mufson, E. J., Levey, A. I., Taylor, M. D., Brown, W. D., et al. (1998). Age-related declines in nigral neuronal function correlate with motor impairments in rhesus monkeys. J. Comp. Neurol. 401, 253-265. doi: 10.1002/(SICI)1096-9861(19981116)401:2<253::AID-CNE7>3.0.CO;2-X

Fonseca, M. S., Murakami, M., and Mainen, Z. F. (2015). Activation of dorsal raphe serotonergic neurons promotes waiting but is not reinforcing. Curr. Biol. 25, 306-315. doi: 10.1016/j.cub.2014.12.002

Foote, S. L., Freedman, R., and Oliver, A. P. (1975). Effects of putative neurotransmitters on neuronal activity in monkey auditory cortex. Brain Res. 86, 229-242. doi: 10.1016/0006-8993(75)90699-X

Foote, S. L., and Morrison, J. H. (1987). Extrathalamic modulation of cortical function. Annu. Rev. Neurosci. 10, 67-95. doi: 10.1146/annurev.ne.10.030187. 000435

Frazão, R., Pinato, L., da Silva, A. V., Britto, L. R., Oliveira, J. A., and Nogueira, M. I. (2008). Evidence of reciprocal connections between the dorsal raphe nucleus and the retina in the monkey Cebus apella. Neurosci. Lett. 430, 119-123. doi: 10.1016/j.neulet.2007.10.032

Fujimiya, M., Kimura, H., and Maeda, T. (1986). Postnatal development of serotonin nerve fibers in the somatosensory cortex of mice studied by immunohistochemistry. J. Comp. Neurol. 246, 191-201. doi: 10.1002/cne. 902460205

Fuster, J. (2015). The Prefrontal Cortex, 5th Edn. Cambridge, MA: Academic Press. Fuxe, K. (1965). Evidence for the existence of monoamine neurons in the central nervous system. IV. Distribution of monoamine nerve terminals in the central nervous system. Acta Physiol. Scand. Suppl. 247:37. doi: 10.1007/BF00337069

Fuxe, K., and Borroto-Escuela, D. O. (2016). Volume transmission and receptorreceptor interactions in heteroreceptor complexes: understanding the role of new concepts for brain communication. Neural Regen. Res. 11, 1220-1223. doi: $10.4103 / 1673-5374.189168$

García-Cabezas, M. A., Martínez-Sánchez, P., Sánchez-González, M. A., Garzón, M., and Cavada, C. (2009). Dopamine innervation in the thalamus: monkey versus rat. Cereb. Cortex 19, 424-434. doi: 10.1093/cercor/bhn093

García-Cabezas, M. A., Rico, B., Sánchez-González, M. A., and Cavada, C. (2007). Distribution of the dopamine innervation in the macaque and human thalamus. Neuroimage 34, 965-984. doi: 10.1016/j.neuroimage.2006.07.032 
German, D. C., and Manaye, K. F. (1993). Midbrain dopaminergic neurons (nuclei A8, A9, and A10): three-dimensional reconstruction in the rat. J. Comp. Neurol. 331, 297-309. doi: 10.1002/cne.903310302

Gittelman, J. X., Perkel, D. J., and Portfors, C. V. (2013). Dopamine modulates auditory responses in the inferior colliculus in a heterogeneous manner. J. Assoc. Res. Otolaryngol. 14, 719-729. doi: 10.1007/s10162-013-0405-0

Goldman-Rakic, P. S., Leranth, C., Williams, S. M., Mons, N., and Geffard, M. (1989). Dopamine synaptic complex with pyramidal neurons in primate cerebral cortex. Proc. Natl. Acad. Sci. U.S.A. 86, 9015-9019. doi: 10.1073/pnas. 86.22.9015

Govindaiah, G., and Cox, C. L. (2005). Excitatory actions of dopamine via D1-like receptors in the rat lateral geniculate nucleus. J. Neurophysiol. 94, 3708-3718. doi: $10.1152 /$ jn.00583.2005

Govindaiah, G., Wang, Y., and Cox, C. L. (2010a). Dopamine enhances the excitability of somatosensory thalamocortical neurons. Neuroscience 170, 981-991. doi: 10.1016/j.neuroscience.2010.08.043

Govindaiah, G., Wang, T., Gillette, M. U., Crandall, S. R., and Cox, C. L. (2010b). Regulation of inhibitory synapses by presynaptic $\mathrm{D}_{4}$ dopamine receptors in thalamus. J. Neurophysiol. 104, 2757-2765. doi: 10.1152/jn.00361.2010

Groenewegen, H. J. (1988). Organization of the afferent connections of the mediodorsal thalamic nucleus in the rat, related to the mediodorsal-prefrontal topography. Neuroscience 24, 379-431. doi: 10.1016/0306-4522(88)90339-9

Grzanna, R., and Molliver, M. E. (1980). The locus coeruleus in the rat: an immunohistochemical delineation. Neuroscience 5, 21-40. doi: 10.1016/03064522(80)90068-8

Happel, M. F. K., Deliano, M., Handschuh, J., and Ohl, F. W. (2014). Dopaminemodulated recurrent corticoefferent feedback in primary sensory cortex promotes detection of behaviorally relevant stimuli. J. Neurosci. 34, 1234-1247. doi: 10.1523/JNEUROSCI.1990-13.2014

Harris, K. D., and Thiele, A. (2011). Cortical state and attention. Nat. Rev. Neurosci. 12, 509-523. doi: 10.1038/nrn3084

Hornung, J. P. (2010). "The neuroanatomy of the serotonergic system," in Handbook of the Behavioral Neurobiology of Serotonin, eds C. P. Mueller and B. L. Jacobs (London: Academic Press), 68-81.

Huntley, G. W., Morrison, J. H., Prikhozhan, A., and Sealfon, S. C. (1992). Localization of multiple dopamine receptor subtype mRNAs in human and monkey motor cortex and striatum. Brain Res. Mol. Brain Res. 15, 181-188. doi: 10.1016/0169-328X(92)90107-M

Hurd, Y. L., Suzuki, M., and Sedvall, G. C. (2001). D1 and D2 dopamine receptor mRNA expression in whole hemisphere sections of the human brain. J. Chem. Neuroanat. 22, 127-137. doi: 10.1016/S0891-0618(01)00122-3

Hurley, L. M., Devilbiss, D. M., and Waterhouse, B. D. (2004). A matter of focus: monoaminergic modulation of stimulus coding in mammalian sensory networks. Curr. Opin. Neurobiol. 14, 488-495. doi: 10.1016/j.conb.2004.06.007

Hurley, L. M., and Pollak, G. D. (1999). Serotonin differentially modulates responses to tones and frequency-modulated sweeps in the inferior colliculus. J. Neurosci. 19, 8071-8082. doi: 10.1523/JNEUROSCI.19-18-08071.1999

Hurley, L. M., and Pollak, G. D. (2005). Serotonin shifts first-spike latencies of inferior colliculus neurons. J. Neurosci. 25, 7876-7886. doi: 10.1523/ JNEUROSCI.1178-05.2005

Ishimura, K., Takeuchi, Y., Fujiwara, K., Tominaga, M., Yoshioka, H., and Sawada, T. (1988). Quantitative analysis of the distribution of serotoninimmunoreactive cell bodies in the mouse brain. Neurosci. Lett. 91, 265-270. doi: 10.1016/0304-3940(88)90691-X

Jacob, S. N., Ott, T., and Nieder, A. (2013). Dopamine regulates two classes of primate prefrontal neurons that represent sensory signals. J. Neurosci. 33, 13724-13734. doi: 10.1523/JNEUROSCI.0210-13.2013

Jacob, S. N., Stalter, M., and Nieder, A. (2016). Cell-type-specific modulation of targets and distractors by dopamine D1 receptors in primate prefrontal cortex. Nat. Commun. 7:13218. doi: 10.1038/ncomms13218

Jacobowitz, D. M., and MacLean, P. D. (1978). A brainstem atlas of catecholaminergic neurons and serotonergic perikarya in a pygmy primate (Cebuella pygmaea). J. Comp. Neurol. 177, 397-416. doi: 10.1002/cne.901770304

Jones, B. E., Halaris, A. E., McIlhany, M., and Moore, R. Y. (1977). Ascending projections of the locus coeruleus in the rat. I. Axonal transport in central noradrenaline neurons. Brain Res. 127, 1-21. doi: 10.1016/0006-8993(77) 90377-8
Kasamatsu, T., and Heggelund, P. (1982). Single cell responses in cat visual cortex to visual stimulation during iontophoresis of noradrenaline. Exp. Brain Res. 45, 317-327. doi: 10.1007/BF01208591

Kayama, Y., Negi, T., Sugitani, M., and Iwama, K. (1982). Effects of locus coeruleus stimulation on neuronal activities of dorsal lateral geniculate nucleus and perigeniculate reticular nucleus of the rat. Neuroscience 7, 655-666. doi: 10.1016/0306-4522(82)90071-9

Kehr, W., Lindqvist, M., and Carlsson, A. (1976). Distribution of dopamine in the rat cerebral cortex. J. Neural Transm. 38, 173-180. doi: 10.1007/BF01249437

Ketzef, M., Spigolon, G., Johansson, Y., Bonito-Oliva, A., Fisone, G., and Silberberg, G. (2017). Dopamine depletion impairs bilateral sensory processing in the striatum in a pathway-dependent manner. Neuron 94, 855-865. doi: 10.1016/j.neuron.2017.05.004

Kim, J. H., Jung, A. H., Jeong, D., Choi, I., Kim, K., Shin, S., et al. (2016). Selectivity of neuromodulatory projections from the basal forebrain and locus ceruleus to primary sensory cortices. J. Neurosci. 36, 5314-5327. doi: 10.1523/JNEUROSCI. 4333- 15.2016

Klepper, A., and Herbert, H. (1991). Distribution and origin of noradrenergic and serotonergic fibers in the cochlear nucleus and inferior colliculus of the rat. Brain Res. 557, 190-201. doi: 10.1016/0006-8993(91)90134-H

Kosofsky, B. E., Molliver, M. E., Morrison, J. H., and Foote, S. L. (1984). The serotonin and norepinephrine innervation of primary visual cortex in the cynomolgus monkey (Macaca fascicularis). J. Comp. Neurol. 230, 168-178. doi: $10.1002 /$ cne. 902300203

Kössl, M., and Vater, M. (1989). Noradrenaline enhances temporal auditory contrast and neuronal timing precision in the cochlear nucleus of the mustached bat. J. Neurosci. 9, 4169-4178. doi: 10.1523/JNEUROSCI.09-1204169.1989

Krakauer, J. W., Ghazanfar, A. A., Gomez-Marin, A., MacIver, M. A., and Poeppel, D. (2017). Neuroscience needs behavior: correcting a reductionist bias. Neuron 93, 480-490. doi: 10.1016/j.neuron.2016.12.041

Kuroda, M., Murakami, K., Igarashi, H., and Okada, A. (1996). The convergence of axon terminals from the mediodorsal thalamic nucleus and ventral tegmental area on pyramidal cells in layer V of the rat prelimbic cortex. Eur. J. Neurosci. 8, 1340-1349. doi: 10.1111/j.1460-9568.1996.tb01596.x

Lammel, S., Hetzel, A., Häckel, O., Jones, I., Liss, B., and Roeper, J. (2008). Unique properties of mesoprefrontal neurons within a dual mesocorticolimbic dopamine system. Neuron 57, 760-773. doi: 10.1016/j.neuron.2008.01.022

Lammel, S., Steinberg, E. E., Földy, C., Wall, N. R., Beier, K., Luo, L., et al. (2015). Diversity of transgenic mouse models for selective targeting of midbrain dopamine neurons. Neuron 85, 429-438. doi: 10.1016/j.neuron.2014.12.036

Lamour, Y., Rivot, J. P., Pointis, D., and Ory-Lavollee, L. (1983). Laminar distribution of serotonergic innervation in rat somatosensory cortex, as determined by in vivo electrochemical detection. Brain Res. 259, 163-166. doi: 10.1016/0006-8993(83)91082-X

Lesch, K. P., and Waider, J. (2012). Serotonin in the modulation of neural plasticity and networks: implications for neurodevelopmental disorders. Neuron 76, 175-191. doi: 10.1016/j.neuron.2012.09.013

Lewis, D. A., Campbell, M. J., Foote, S. L., Goldstein, M., and Morrison, J. H. (1987). The distribution of tyrosine hydroxylase-immunoreactive fibers in primate neocortex is widespread but regionally specific. J. Neurosci. 7, 279-290. doi: 10.1523/JNEUROSCI.07-01-00279.1987

Lidow, M. S., Goldman-Rakic, P. S., Gallager, D. W., and Rakic, P. (1991). Distribution of dopaminergic receptors in the primate cerebral cortex: quantitative autoradiographic analysis using $[3 \mathrm{H}]$ raclopride, $[3 \mathrm{H}]$ spiperone and $[3 \mathrm{H}] \mathrm{SCH} 23390$. Neuroscience 40, 657-671. doi: 10.1016/0306-4522(91) 90003-7

Lidow, M. S., Wang, F., Cao, Y., and Goldman-Rakic, P. S. (1998). Layer V neurons bear the majority of mRNAs encoding the five distinct dopamine receptor subtypes in the primate prefrontal cortex. Synapse 28, 10-20. doi: 10.1002/ (SICI)1098-2396(199801)28:1<10::AID-SYN2>3.0.CO;2-F

Lottem, E., Banerjee, D., Vertechi, P., Sarra, D., Lohuis, M. O., and Mainen, Z. F. (2018). Activation of serotonin neurons promotes active persistence in a probabilistic foraging task. Nat. Commun. 9:1000. doi: 10.1038/s41467-01803438-y

Lottem, E., Lörincz, M. L., and Mainen, Z. F. (2016). Optogenetic activation of dorsal raphe serotonin neurons rapidly inhibits spontaneous but not 
odor-evoked activity in olfactory cortex. J. Neurosci. 36, 7-18. doi: 10.1523/ JNEUROSCI.3008-15.2016

Loughlin, S. E., and Fallon, J. H. (1984). Substantia nigra and ventral tegmental area projections to cortex: topography and collateralization. Neuroscience 11, 425-435. doi: 10.1016/0306-4522(84)90034-4

Loughlin, S. E., Foote, S. L., and Bloom, F. E. (1986). Efferent projections of nucleus locus coeruleus: topographic organization of cells of origin demonstrated by three-dimensional reconstruction. Neuroscience 18, 291-306. doi: 10.1016/ 0306-4522(86)90155-7

Manella, L. C., Petersen, N., and Linster, C. (2017). Stimulation of the locus ceruleus modulates signal-to-noise ratio in the olfactory bulb. J. Neurosci. 37, 11605-11615. doi: 10.1523/JNEUROSCI.2026-17.2017

Manunta, Y., and Edeline, J. M. (1997). Effects of noradrenaline on frequency tuning of rat auditory cortex neurons. Eur. J. Neurosci. 9, 833-847. doi: 10.1111/ j.1460-9568.1997.tb01433.x

Matsumoto, M., and Hikosaka, O. (2009). Two types of dopamine neuron distinctly convey positive and negative motivational signals. Nature 459, 837-841. doi: $10.1038 /$ nature 08028

Matsumoto, M., Matsumoto, M., Takada, M., and Takada, M. (2013). Distinct representations of cognitive and motivational signals in midbrain dopamine neurons. Neuron 79, 1011-1024. doi: 10.1016/j.neuron.2013.07.002

McLean, J., and Waterhouse, B. D. (1994). Noradrenergic modulation of cat area 17 neuronal responses to moving visual stimuli. Brain Res. 667, 83-97. doi: 10.1016/0006-8993(94)91716-7

McLean, J. H., and Shipley, M. T. (1987). Serotonergic afferents to the rat olfactory bulb: I. Origins and laminar specificity of serotonergic inputs in the adult rat. J. Neurosci. 7, 3016-3028. doi: 10.1523/JNEUROSCI.07-10-03016.1987

McLean, J. H., Shipley, M. T., Nickell, W. T., Aston-Jones, G., and Reyher, C. K. (1989). Chemoanatomical organization of the noradrenergic input from locus coeruleus to the olfactory bulb of the adult rat. J. Comp. Neurol. 285, 339-349. doi: $10.1002 /$ cne. 902850305

Melchitzky, D. S., Erickson, S. L., and Lewis, D. A. (2006). Dopamine innervation of the monkey mediodorsal thalamus: location of projection neurons and ultrastructural characteristics of axon terminals. Neuroscience 143, 1021-1030. doi: 10.1016/j.neuroscience.2006.08.056

Mengod, G., Cortes, R., Vilaro, M. T., and Hoyer, D. (2010). "Distribution of 5-HT receptors in the central nervous system," in Handbook of the Behavioral Neurobiology of Serotonin, eds C. P. Mueller and B. L. Jacobs (London: Academic Press), 140-155.

Missale, C., Nash, S. R., Robinson, S. W., Jaber, M., and Caron, M. G. (1998). Dopamine receptors: from structure to function. Physiol. Rev. 78, 189-225. doi: 10.1152/physrev.1998.78.1.189

Miyazaki, K. W., Miyazaki, K., Tanaka, K. F., Yamanaka, A., Takahashi, A., Tabuchi, S., et al. (2014). Optogenetic activation of dorsal raphe serotonin neurons enhances patience for future rewards. Curr. Biol. 24, 2033-2040. doi: $10.1016 /$ j.cub.2014.07.041

Moore, R. Y., and Bloom, F. E. (1979). Central catecholamine neuron systems: anatomy and physiology of the norepinephrine and epinephrine systems. Annu. Rev. Neurosci. 2, 113-168. doi: 10.1146/annurev.ne.02.030179.000553

Morrison, J. H., and Foote, S. L. (1986). Noradrenergic and serotoninergic innervation of cortical, thalamic, and tectal visual structures in Old and New World monkeys. J. Comp. Neurol. 243, 117-138. doi: 10.1002/cne.902430110

Morrison, J. H., Foote, S. L., Molliver, M. E., Bloom, F. E., and Lidov, H. G. (1982a). Noradrenergic and serotonergic fibers innervate complementary layers in monkey primary visual cortex: an immunohistochemical study. Proc. Natl. Acad. Sci. U.S.A. 79, 2401-2405.

Morrison, J. H., Foote, S. L., O'Connor, D., and Bloom, F. E. (1982b). Laminar, tangential and regional organization of the noradrenergic innervation of monkey cortex: dopamine-beta-hydroxylase immunohistochemistry. Brain Res. Bull. 9, 309-319.

Muller, A., Joseph, V., Slesinger, P. A., and Kleinfeld, D. (2014). Cell-based reporters reveal in vivo dynamics of dopamine and norepinephrine release in murine cortex. Nat. Methods 11, 1245-1252. doi: 10.1038/nmeth.3151

Munsch, T., Yanagawa, Y., Obata, K., and Pape, H.-C. (2005). Dopaminergic control of local interneuron activity in the thalamus. Eur. J. Neurosci. 21, 290-294. doi: 10.1111/j.1460-9568.2004.03842.x

Nelson, E. L., Liang, C. L., Sinton, C. M., and German, D. C. (1996). Midbrain dopaminergic neurons in the mouse: computer-assisted mapping. J. Comp.
Neurol. 369, 361-371. doi: 10.1002/(SICI)1096-9861(19960603)369:3<361:: AID-CNE3>3.0.CO;2-3

Neves, R. M., van Keulen, S., Yang, M., Logothetis, N. K., and Eschenko, O. (2018). Locus coeruleus phasic discharge is essential for stimulus-induced gamma oscillations in the prefrontal cortex. J. Neurophysiol. 119, 904-920. doi: 10.1152/ jn.00552.2017

Nevue, A. A., Elde, C. J., Perkel, D. J., and Portfors, C. V. (2015). Dopaminergic input to the inferior colliculus in mice. Front. Neuroanat. 9:168. doi: 10.3389/ fnana.2015.00168

Niell, C. M., and Stryker, M. P. (2010). Modulation of visual responses by behavioral state in mouse visual cortex. Neuron 65, 472-479. doi: 10.1016/j. neuron.2010.01.033

Noudoost, B., and Moore, T. (2011). Control of visual cortical signals by prefrontal dopamine. Nature 474, 372-375. doi: 10.1038/nature09995

O'Hanlon, J. F. (1965). Adrenaline and noradrenaline: relation to performance in a visual vigilance task. Science 150, 507-509. doi: 10.1126/science.150.3695.507

Ott, T., Jacob, S. N., and Nieder, A. (2014). Dopamine receptors differentially enhance rule coding in primate prefrontal cortex neurons. Neuron 84, 1317-1328. doi: 10.1016/j.neuron.2014.11.012

Papadopoulos, G. C., and Parnavelas, J. G. (1990). Distribution and synaptic organization of dopaminergic axons in the lateral geniculate nucleus of the rat. J. Comp. Neurol. 294, 356-361. doi: 10.1002/cne.902940305

Papadopoulos, G. C., and Parnavelas, J. G. (1991). Monoamine systems in the cerebral cortex: evidence for anatomical specificity. Prog. Neurobiol. 36, 195-200. doi: 10.1016/0301-0082(91)90030-5

Papadopoulos, G. C., Parnavelas, J. G., and Buijs, R. M. (1989). Light and electron microscopic immunocytochemical analysis of the noradrenaline innervation of the rat visual cortex. J. Neurocytol. 18, 1-10. doi: 10.1007/BF011 88418

Paspalas, C. D., and Papadopoulos, G. C. (2001). Serotoninergic afferents preferentially innervate distinct subclasses of peptidergic interneurons in the rat visual cortex. Brain Res. 891, 158-167. doi: 10.1016/S0006-8993(00)03193-0

Petzold, G. C., Hagiwara, A., and Murthy, V. N. (2009). Serotonergic modulation of odor input to the mammalian olfactory bulb. Nat. Neurosci. 12, 784-791. doi: $10.1038 / \mathrm{nn} .2335$

Phillipson, O. T., Kilpatrick, I. C., and Jones, M. W. (1987). Dopaminergic innervation of the primary visual cortex in the rat, and some correlations with human cortex. Brain Res. Bull. 18, 621-633. doi: 10.1016/0361-9230(87)90132-8

Phillis, J. W., and Teběcis, A. K. (1967). The responses of thalamic neurons to iontophoretically applied monoamines. J. Physiol. 192, 715-745. doi: 10.1113/ jphysiol.1967.sp008327

Phillis, J. W., Teběcis, A. K., and York, D. H. (1967). The inhibitory action of monoamines on lateral geniculate neurones. J. Physiol. 190, 563-581. doi: 10.1113/jphysiol.1967.sp008228

Polack, P. O., Friedman, J., and Golshani, P. (2013). Cellular mechanisms of brain state-dependent gain modulation in visual cortex. Nat. Neurosci. 16, 1331-1339. doi: 10.1038/nn.3464

Pollak Dorocic, I., Fürth, D., Xuan, Y., Johansson, Y., Pozzi, L., Silberberg, G., et al. (2014). A whole-brain atlas of inputs to serotonergic neurons of the dorsal and median raphe nuclei. Neuron 83, 663-678. doi: 10.1016/j.neuron.2014.07.002

Rabinowitz, N. C., Goris, R. L., Cohen, M., and Simoncelli, E. (2015). Attention stabilizes the shared gain of V4 populations. eLife 4:e08998. doi: 10.7554/eLife. 08998

Ramos, B. P., and Arnsten, A. F. (2007). Adrenergic pharmacology and cognition: focus on the prefrontal cortex. Pharmacol. Ther. 113, 523-536. doi: 10.1016/j. pharmthera.2006.11.006

Ranade, S., Pi, H. J., and Kepecs, A. (2014). Neuroscience: waiting for serotonin. Curr. Biol. 24, R803-R805. doi: 10.1016/j.cub.2014.07.024

Ranade, S. P., and Mainen, Z. F. (2009). Transient firing of dorsal raphe neurons encodes diverse and specific sensory, motor, and reward events. J. Neurophysiol. 102, 3026-3037. doi: 10.1152/jn.00507.2009

Rauch, A., Rainer, G., and Logothetis, N. K. (2008). The effect of a serotonininduced dissociation between spiking and perisynaptic activity on BOLD functional MRI. Proc. Natl. Acad. Sci. U.S.A. 105, 6759-6764. doi: 10.1073/pnas. 0800312105

Reimer, J., Froudarakis, E., Cadwell, C. R., Yatsenko, D., Denfield, G. H., and Tolias, A. S. (2014). Pupil fluctuations track fast switching of cortical states during quiet wakefulness. Neuron 84, 355-362. doi: 10.1016/j.neuron.2014.09.033 
Reimer, J., McGinley, M. J., Liu, Y., Rodenkirch, C., Wang, Q., McCormick, D. A., et al. (2016). Pupil fluctuations track rapid changes in adrenergic and cholinergic activity in cortex. Nat. Commun. 7:13289. doi: 10.1038/ ncomms 13289

Rice, M. E., and Cragg, S. J. (2008). Dopamine spillover after quantal release: rethinking dopamine transmission in the nigrostriatal pathway. Brain Res. Rev. 58, 303-313. doi: 10.1016/j.brainresrev.2008.02.004

Rogawski, M. A., and Aghajanian, G. K. (1980). Modulation of lateral geniculate neurone excitability by noradrenaline microiontophoresis or locus coeruleus stimulation. Nature 287, 731-734. doi: 10.1038/287731a0

Rudy, B., Fishell, G., Lee, S., and Hjerling-Leffler, J. (2011). Three groups of interneurons account for nearly $100 \%$ of neocortical GABAergic neurons. Dev. Neurobiol. 71, 45-61. doi: 10.1002/dneu.20853

Safaai, H., Neves, R., Eschenko, O., Logothetis, N. K., and Panzeri, S. (2015). Modeling the effect of locus coeruleus firing on cortical state dynamics and single-trial sensory processing. Proc. Natl. Acad. Sci. U.S.A. 112, 12834-12839. doi: 10.1073 /pnas.1516539112

Sánchez-González, M. A., García-Cabezas, M. A., Rico, B., and Cavada, C. (2005). The primate thalamus is a key target for brain dopamine. J. Neurosci. 25, 6076-6083. doi: 10.1523/JNEUROSCI.0968-05.2005

Santana, N., Mengod, G., and Artigas, F. (2009). Quantitative analysis of the expression of dopamine D1 and D2 receptors in pyramidal and GABAergic neurons of the rat prefrontal cortex. Cereb. Cortex 19, 849-860. doi: 10.1093/ cercor/bhn134

Sara, S. J., and Bouret, S. (2012). Orienting and reorienting: the locus coeruleus mediates cognition through arousal. Neuron 76, 130-141. doi: 10.1016/j. neuron.2012.09.011

Sarter, M., Parikh, V., and Howe, W. M. (2009). Phasic acetylcholine release and the volume transmission hypothesis: time to move on. Nat. Rev. Neurosci. 10, 383-390. doi: 10.1038/nrn2635

Sato, H., Fox, K., and Daw, N. W. (1989). Effect of electrical stimulation of locus coeruleus on the activity of neurons in the cat visual cortex. J. Neurophysiol. 62, 946-958. doi: 10.1152/jn.1989.62.4.946

Schicknick, H., Reichenbach, N., Smalla, K.-H., Scheich, H., Gundelfinger, E. D., and Tischmeyer, W. (2012). Dopamine modulates memory consolidation of discrimination learning in the auditory cortex. Eur. J. Neurosci. 35, 763-774. doi: 10.1111/j.1460-9568.2012.07994.x

Schicknick, H., Schott, B. H., Budinger, E., Smalla, K.-H., Riedel, A., Seidenbecher, C. I., et al. (2008). Dopaminergic modulation of auditory cortex-dependent memory consolidation through mTOR. Cereb. Cortex 18, 2646-2658. doi: 10.1093/cercor/bhn026

Schnyder, H., and Künzle, H. (1984). Is there a retinopetal system in the rat. Exp. Brain Res. 56, 502-508. doi: 10.1007/BF00237991

Schölvinck, M. L., Saleem, A. B., Benucci, A., Harris, K. D., and Carandini, M. (2015). Cortical state determines global variability and correlations in visual cortex. J. Neurosci. 35, 170-178. doi: 10.1523/JNEUROSCI.4994-13.2015

Schultz, W. (2007). Multiple dopamine functions at different time courses. Annu. Rev. Neurosci. 30, 259-288. doi: 10.1146/annurev.neuro.28.061604.135722

Seillier, L., Lorenz, C., Kawaguchi, K., Ott, T., Nieder, A., Pourriahi, P., et al. (2017). Serotonin decreases the gain of visual responses in awake macaque V1. J. Neurosci. 37, 11390-11405. doi: 10.1523/JNEUROSCI.1339-17.2017

Sherman, S. M. (2016). Thalamus plays a central role in ongoing cortical functioning. Nat. Neurosci. 19, 533-541. doi: 10.1038/nn.4269

Smiley, J. F., Levey, A. I., Ciliax, B. J., and Goldman-Rakic, P. S. (1994). D1 dopamine receptor immunoreactivity in human and monkey cerebral cortex: predominant and extrasynaptic localization in dendritic spines. Proc. Natl. Acad. Sci. U.S.A. 91, 5720-5724. doi: 10.1073/pnas.91.12.5720

Soubrie, P. (1986). Reconciling the role of central serotonin neurons in human and animal behavior. Behav. Brain Sci. 9, 319-335. doi: 10.1017/ S0140525X00022871

Sulzer, D., Cragg, S. J., and Rice, M. E. (2016). Striatal dopamine neurotransmission: regulation of release and uptake. Basal Ganglia 6, 123-148. doi: 10.1016/j.baga.2016.02.001

Takeuchi, T., Duszkiewicz, A. J., Sonneborn, A., Spooner, P. A., Yamasaki, M., Watanabe, M., et al. (2016). Locus coeruleus and dopaminergic consolidation of everyday memory. Nature 537, 357-362. doi: 10.1038/nature19325
Takeuchi, Y., Kimura, H., and Sano, Y. (1982). Immunohistochemical demonstration of serotonin nerve fibers in the olfactory bulb of the rat, cat and monkey. Histochemistry 75, 461-471.

Takeuchi, Y., and Sano, Y. (1984). Serotonin nerve fibers in the primary visual cortex of the monkey. Quantitative and immunoelectronmicroscopical analysis. Anat. Embryol. 169, 1-8. doi: 10.1007/BF00300581

Tigges, J., Tigges, M., Cross, N. A., McBride, R. L., Letbetter, W. D., and Anschel, S. (1982). Subcortical structures projecting to visual cortical areas in squirrel monkey. J. Comp. Neurol. 209, 29-40. doi: 10.1002/cne.902090104

Tong, L., Altschuler, R. A., and Holt, A. G. (2005). Tyrosine hydroxylase in rat auditory midbrain: distribution and changes following deafness. Hear. Res. 206, 28-41. doi: 10.1016/j.heares.2005.03.006

Uematsu, A., Tan, B. Z., Ycu, E. A., Cuevas, J. S., Koivumaa, J., Junyent, F., et al. (2017). Modular organization of the brainstem noradrenaline system coordinates opposing learning states. Nat. Neurosci. 20, 1602-1611. doi: $10.1038 / \mathrm{nn} .4642$

Varela, C. (2014). Thalamic neuromodulation and its implications for executive networks. Front. Neural Circuits 8:69. doi: 10.3389/fncir.2014.00069

Vertes, R. P., Linley, S. B., and Hoover, W. B. (2010). Pattern of distribution of serotonergic fibers to the thalamus of the rat. Brain Struct. Funct. 215, 1-28. doi: 10.1007/s00429-010-0249-x

Vijayraghavan, S., Wang, M., Birnbaum, S. G., von Williams, G., and Arnsten, A. F. T. (2007). Inverted-U dopamine D1 receptor actions on prefrontal neurons engaged in working memory. Nat. Neurosci. 10, 376-384. doi: 10.1038/ nn1846

Villar, M. J., Vitale, M. L., Hökfelt, T., and Verhofstad, A. A. (1988). Dorsal raphe serotoninergic branching neurons projecting both to the lateral geniculate body and superior colliculus: a combined retrograde tracing-immunohistochemical study in the rat. J. Comp. Neurol. 277, 126-140. doi: 10.1002/cne.9027 70109

Vincent, S. L., Khan, Y., and Benes, F. M. (1993). Cellular distribution of dopamine D1 and D2 receptors in rat medial prefrontal cortex. J. Neurosci. 13, 2551-2564. doi: 10.1523/JNEUROSCI.13-06-02551.1993

Watakabe, A., Komatsu, Y., Sadakane, O., Shimegi, S., Takahata, T., Higo, N., et al. (2009). Enriched expression of serotonin $1 \mathrm{~B}$ and $2 \mathrm{~A}$ receptor genes in macaque visual cortex and their bidirectional modulatory effects on neuronal responses. Cereb. Cortex 19, 1915-1928. doi: 10.1093/cercor/bhn219

Waterhouse, B. D., Azizi, S. A., Burne, R. A., and Woodward, D. J. (1990). Modulation of rat cortical area 17 neuronal responses to moving visual stimuli during norepinephrine and serotonin microiontophoresis. Brain Res. 514, 276-292. doi: 10.1016/0006-8993(90)91422-D

Waterhouse, B. D., Lin, C. S., Burne, R. A., and Woodward, D. J. (1983). The distribution of neocortical projection neurons in the locus coeruleus. J. Comp. Neurol. 217, 418-431. doi: 10.1002/cne.902170406

Waterhouse, B. D., Moises, H. C., and Woodward, D. J. (1980). Noradrenergic modulation of somatosensory cortical neuronal responses to iontophoretically applied putative neurotransmitters. Exp. Neurol. 69, 30-49. doi: 10.1016/00144886(80)90141-7

Waterhouse, B. D., Moises, H. C., and Woodward, D. J. (1986). Interaction of serotonin with somatosensory cortical neuronal responses to afferent synaptic inputs and putative neurotransmitters. Brain Res. Bull. 17, 507-518. doi: 10.1016/0361-9230(86)90218-2

Waterhouse, B. D., Moises, H. C., and Woodward, D. J. (1998). Phasic activation of the locus coeruleus enhances responses of primary sensory cortical neurons to peripheral receptive field stimulation. Brain Res. 790, 33-44. doi: 10.1016/ S0006-8993(98)00117-6

Waterhouse, B. D., and Woodward, D. J. (1980). Interaction of norepinephrine with cerebrocortical activity evoked by stimulation of somatosensory afferent pathways in the rat. Exp. Neurol. 67, 11-34. doi: 10.1016/0014-4886(80) 90159-4

Weiner, D. M., Levey, A. I., Sunahara, R. K., Niznik, H. B., O’Dowd, B. F., Seeman, P., et al. (1991). D1 and D2 dopamine receptor mRNA in rat brain. Proc. Natl. Acad. Sci. U.S.A. 88, 1859-1863. doi: 10.1073/pnas.88.5.1859

Williams, S. M., and Goldman-Rakic, P. S. (1998). Widespread origin of the primate mesofrontal dopamine system. Cereb. Cortex 8, 321-345. doi: 10.1093/cercor/8. 4.321 
Wilson, M. A., and Molliver, M. E. (1991a). The organization of serotonergic projections to cerebral cortex in primates: regional distribution of axon terminals. Neuroscience 44, 537-553.

Wilson, M. A., and Molliver, M. E. (1991b). The organization of serotonergic projections to cerebral cortex in primates: retrograde transport studies. Neuroscience 44, 555-570.

Zaldivar, D., Goense, J., Lowe, S. C., Logothetis, N. K., and Panzeri, S. (2018). Dopamine is signaled by mid-frequency oscillations and boosts output layers visual information in visual cortex. Curr. Biol. 28, 224.e5-235.e5. doi: 10.1016/ j.cub.2017.12.006

Zaldivar, D., Rauch, A., Whittingstall, K., Logothetis, N. K., and Goense, J. (2014). Dopamine-induced dissociation of BOLD and neural activity in macaque visual cortex. Curr. Biol. 24, 2805-2811. doi: 10.1016/j.cub.2014. 10.006
Zhao, Y., Kerscher, N., Eysel, U., and Funke, K. (2002). D1 and D2 receptormediated dopaminergic modulation of visual responses in cat dorsal lateral geniculate nucleus. J. Physiol. 539(Pt 1), 223-238.

Conflict of Interest Statement: The authors declare that the research was conducted in the absence of any commercial or financial relationships that could be construed as a potential conflict of interest.

Copyright (c) 2018 Jacob and Nienborg. This is an open-access article distributed under the terms of the Creative Commons Attribution License (CC BY). The use, distribution or reproduction in other forums is permitted, provided the original author(s) and the copyright owner(s) are credited and that the original publication in this journal is cited, in accordance with accepted academic practice. No use, distribution or reproduction is permitted which does not comply with these terms. 